\title{
13. SHALLOW-WATER FORAMINIFERS AND ASSOCIATED MICROFOSSILS FROM SITES 315, 316, AND 318, DSDP LEG 33
}

\author{
J.P. Beckmann, Geological Institute, Federal School of Technology, Zürich, Switzerland
}

\section{INTRODUCTION}

This report includes a brief description and discussion of some presumably allochthonous microfossils, which were discovered at three drilling sites of DSDP Leg 33 in the Central Pacific Ocean. Two of these sites, 315 and 316 , are situated along the Line Islands Seamount chain, the third one, 318 , in the area of the Tuamotu Ridge. These fossils, which are normally indicators of a shallow-water habitat, are now components of pelagic deep-water sediments. These heterogeneous fossil associations usually occur in sediments with distinctive textural characteristics, such as grading, sorting, relatively coarse grain, disturbed stratification, and others. Some layers contain various fragments of volcanic and sedimentary rocks. The sorting of the sedimentary particles has also affected the size range of the microfossil remains, which is in most cases between 0.6 and $2 \mathrm{~mm}$.

The age of the shallow-water fossils at Sites 315 and 316 is Late Cretaceous (partly reworked into the Tertiary), while at Site 318 it ranges from Eocene to PlioPleistocene. The most commonly represented taxonomic groups are larger foraminifers (Nummulitidae, Pseudorbitoididae, Orbitoididae, Discocyclinidae), bryozoans, mollusks, and, more rarely, corals and coralline algae.

The samples which are now available for examination were collected on the ship. They consist of washed residues (sometimes only the coarse fraction) and thin sections and a few small chips of limestone. I cannot judge how complete the sampling was. Possibly it should be more detailed in order to be representative, and should include a thorough study of some individual turbidite layers. The results presented in the present report should therefore be regarded as strictly preliminary. The number of specimens is relatively small, and the preservation sometimes poor (abraded edges and surfaces; soft, chalky wall material). The selective sorting of the components must have artificially distorted the original size range of the species and also the original composition of the associations. Consequently, the taxonomic determinations must remain provisional in many cases. Similarly, it is possible that the conclusions on the age and the origin of the material, presented in the last two paragraphs of this note, may have to be reviewed and modified in the course of a more exhaustive study.

Among the determinable fossil remains in the present material, the larger foraminifers are the most common and most diversified. In the Cretaceous, the predominant genera are Pseudorbitoides, Asterorbis, and Sulcoperculina. The absence of Orbitoides is noteworthy. Among the faunas from the Tertiary, Amphistegina, Heterostegina, Nummulites, and Asterocyclina are the characteristic genera. In the Neogene of Site 318 , there is a fairly rich bryozoan assemblage which includes the genera Margaretta, Idmonea, and Filisparsa (determined by R. Lagaaij). The mollusks, corals, and coralline algae occur as small fragments only; no effort has been made to determine them. The most significant fossils are figured on Plates 1-9. In most cases, the photographs have been arranged in such a way that each plate shows the contents of one sample.

Shallow-water fossils, which are usually regarded as redeposited, have been repeatedly found during the recent operations of the Deep Sea Drilling Project. Examples are Sites 24 (Leg 4), 98 (Leg 11), and 142 (Leg 14) from the Atlantic Ocean. In the Pacific, similar records are sparse. Fossil oolitic sand with unidentified reef debris was found on West Pacific seamounts (e.g., Site 202, Leg 20). A significant discovery is that of unidentified pseudorbitoids in the Upper Cretaceous of the Central Pacific Site 165, in the core-catcher sample of Core 16 (Winterer, Ewing, et al., 1973, p. 81). Almost all previously known occurrences of pseudorbitoids and of Sulcoperculina are situated in the Caribbean and surrounding areas, apart from the single interesting record from New Guinea (Glaessner, 1960). We still know very little about the Cretaceous larger foraminifers and associated fossils in the Pacific (Dilley, 1973), but we must suspect now that faunas of the Caribbean type were widespread in the tropical Pacific. In the Tertiary, however, certainly from the late Eocene onward, the Pacific fauna of larger foraminifers is distinct from that of Central America. We know this especially from the excellent descriptions in the reports of the U.S. Geological Survey (Cole, 1954, 1957a, 1957b, 1959, $1963,1969)$. The Tertiary larger foraminifers from Site 318 are definitely of this Pacific type.

The shallow-water fossils in the sediments drilled during Leg 33 have not only added to our knowledge of the paleogeography of these fossils, but are certainly also an important tool for deciphering the geologic history of the Central Pacific sea floor.

\section{DESCRIPTION AND DISCUSSION OF THE SAMPLES}

\section{A-9, CC (Plate 1)}

The washed residue consists mainly of planktonic foraminifers of Oligocene age. The most conspicuous larger components are cylindrical tubes which apparently consist of indurated sediment (Plate 1, Figure 7). In addition, the following larger foraminifers were found: Pseudorbitoides $\mathrm{cf}$. israelskyi Vaughan and Cole (six specimens), Asterorbis cf. havanensis Palmer (three specimens), Sulcoperculina vermunti Thiadens (four specimens). 
The larger foraminifers indicate a Late Cretaceous (Campanian to ?Maestrichtian) age and must be reworked.

\section{5-10-3, 134-135 cm (Plate 2)}

The available material consists of seven thin sections of a hard limestone with volcanogenic components. The abundant planktonic microfauna consists of globigernids (Tertiary types), radiolarians, Globorotalia? sp. (Plate 2, Figure 6), some reworked specimens of Globotruncana (Plate 2, Figures 5, 11), and rudistid fragments. Also present are scattered larger foraminifers (about one per $\mathrm{cm}^{2}$ ) such as: Pseudorbitoides sp. and undetermined pseudorbitoids, Asterorbis sp., Lepidorbitoides? sp., Sulcoperculina vermunti Thiadens.

These foraminifers must be reworked, together with the globotruncanids and rudistid fragments already mentioned, and one piece of Cretaceous limestone with calcisphaerulids and Hedbergella sp.

\section{A-17-2, 112-114 cm (Plate 3)}

The examined material consists of three thin sections of a hard, calcarenitic limestone. The tightly packed and fairly well sorted grains are mostly fossils such as globotruncanids, smaller benthonic foraminifers, larger foraminifers, unidentified megafossil fragments, and rare small pieces of corallinacean algae and rudistids. The larger foraminifers include: Sulcoperculina vermunti Thiadens and unidentified Pseudorbitoididae.

The coarser components appear to be heterogeneous and to show signs of transportation, but there is no proof of mixing of different ages.

\section{6-27-3, 67-69 cm (Plate 4)}

The sample is a chalky ooze with globotruncanids indicating a Late Cretaceous (Campanian) age. There are about 20 specimens of larger foraminifers, of which nearly all appear to be Pseudorbitoides israelskyi Vaughan and Cole. Most of these (Plate 4, Figures 1-7) are exceptionally small $(0.6-0.9 \mathrm{~mm}$ in diameter).

\section{8-2-2, 15-17 cm (Plate 5)}

The sample is a soft chalky limestone with abundant planktonic foraminifers of Pliocene age. The washed residue includes a conspicuous coarse fraction in which Amphistegina spp., bryozoans, pelecypod fragments, and pieces of corals (?) are the most common elements. The larger foraminifers include: Amphistegina spp. (common), Heterostegina suborbicularis d'Orbigny (sensu W.S. Cole).

The following broyzoans have been determined by $\mathrm{R}$. Lagaaij: Margaretta aff. gracilior (Ortmann), Idmonea (two spp.), Filisparsa sp.

Since all these fossils can occur in the Pliocene, there is no proof that any of them is reworked.

\section{8-2, CC (Plate 6)}

The association is similar to the one above. Determination of the larger skeletal particles is rather difficult because of a finely crystalline overgrowth. There are remains of mollusks, bryozoans, and echinoderms, together with the following larger foraminifers: Amphi- stegina (at least two species), fairly common, Heterostegina cf. suborbicularis d'Orbigny (rare), Heterostegina sp. indet. (very rare).

318-10-1, Interval Unknown (Plate 7, Figures 1-3):

The only available material is a slide with four fragments of larger foraminifers: Heterostegina sp. (two fragments), Lepidocyclina s.l., sp. indet. (two fragments).

The early Miocene age for this sample, determined by the shipboard party, is not disproved by these foraminifers.

\section{8-18-2, 47-49 cm (Plate 7, Figures 4-12)}

Apart from Eocene planktonic foraminifers, the washed residue contains a fair number of larger foraminifers (mainly Asterocyclina) and smaller benthonic foraminifers, as well as a few fragments of mollusks, bryozoans, and echinoderms. The larger foraminifers include: Asterocyclina elongaticamera Cole (common), Asterocyclina sp. indet. (rare), Nummulites sp. aff. $N$. variolarius (Lamarck), rare.

\section{8-19-2, 134-138 cm (Plate 8; Plate 9, Figure 1)}

The available sample is the coarse fraction of the washed residue of a chalky limestone with common chert fragments. It contains relatively few shallow-water particles, such as pieces of corals and hydrozoans?, together with the following larger foraminifers: Nummulites sp. aff. $N$. variolarius (Lamarck) (four specimens), Nummulites sp. indet. (Plate 8, Figures 6, 9) (rare), Heterostegina sp. indet. (three specimens), Cycloclypeus? sp. (one specimen), Asterocyclina elongaticamera Cole (two specimens).

The sample looks rather heterogeneous, but there is no proof of a difference in age from that given by the shipboard party (late Eocene).

\section{8-26-1, 137-140 cm (Plate 9, Figures 2-8)}

The only available sample is one thin section of a hard limestone. It consists almost exclusively of tightly packed foraminifers, together with a few bryozoans and broken pieces of corallinacean algae. The foraminifers are mostly broken or abraded discocyclinids (Discocyclina, Asterocyclina), but there are also some globigerinids and globorotaliids (Acarinina or Truncorotaloides), which indicate an early to middle Eocene age.

\section{NOTES ON THE TAXONOMY OF THE ALLOCHTHONOUS FORAMINIFERS}

It has already been noted in the introduction that the present paper is a preliminary report, and does not include a thorough taxonomic study of the various displaced shallow-water fossils. The larger foraminifers discussed below have been determined by comparisons with the literature on the Cretaceous foraminifers of Central America, most of which is summarized in the excellent "Catalog of Index Larger Foraminifera" (Am. Mus. Nat. Hist., 1966), and with the papers on the Tertiary of the Indo-Pacific faunas mentioned in the introduction and in this paragraph. 


\section{Cretaceous Foraminifers}

Asterorbis: The free specimens from Sample 315A-9, CC (Plate 1, Figures 3, 5, 6) appear to be closely related to $A$. havanensis Palmer. It is possible that the random sections from Core 315A-10 (Plate 2, Figures 2, 4) represent the same species.

Lepidorbitoides: Two cross-sections from Core 315A10 (Plate 2, Figures 7,8) are tentatively referred to this genus.

Pseudorbitoides: A number of free specimens from cores 315A-9 and 316-27 show distinctive characters of the genus Pseudorbitoides (periembryonic chamber arrangement, radial plates) and can be referred to the group of $P$. israelskyi Vaughan and Cole (Plate 1, Figures 1, 2, 4; Plate 4, Figures 1-9). The random sections on Plate 2 (Figures 1, 3) and Plate 3 (Figures 1, 3, $4,5)$ are more difficult to interpret and are here designated as undetermined members of the Family Pseudorbitoididae.

Sulcoperculina: This genus is found in all three samples of Site 315 . It seems to be represented by a single species, $S$. vermunti Thiadens (Plate 1, Figures 8 , 9; Plate 2, Figures 9, 10; Plate 3, Figures 6, 7).

\section{Tertiary Foraminifers}

Amphistegina: The two samples of Core 318-2 contain several, possibly four, undetermined species of Amphistegina (Plate 5, Figures 4-9; Plate 6, Figures 612). They are here informally named species A, B, C, and $\mathrm{D}$.

Asterocyclina: A characteristically rather small species (maximum diameter $1.9 \mathrm{~mm}$ ) occurs commonly in Core 318-18, rarely also in Core 318-19. Its rays (5, rarely 6) are often visible externally as radial ridges. It can be referred to $A$. elongaticamera Cole, originally described from a seamount in the Tuamotu area, not far from the present Site 318 (Plate 7, Figures 4, 5, 6, 9). It is associated with another, undetermined, Asterocyclina species (Plate 7, Figures 7,8). The genus Asterocyclina is also represented among the numerous random sections of discocyclinids in Core 318-26 (Plate 9, Figures 4-6, 8).

Cycloclypeus: The sample of the Eocene Core 318-19 contains a specimen which probably developed annular series of chamberlets, a characteristic of the genus Cycloclypeus (Plate 8, Figures 4, 5). Its external ornamentation resembles that of the poorly described $C$. papillosus Hadley from the Eocene of Cuba. According to Harland et al. (1967) and Adams (1970), there are no records of genuine Cycloclypeus in the Eocene.

Heterostegina: Several species of this genus occur in four samples of Site 318 (Eocene to ?Pliocene), but specimens are always rare. Lenticular tests with a rather narrow spiral and about 20 operculine chambers can be referred to " $H$. suborbicularis d'Orbigny" as described by Cole $(1954,1969)$ from Bikini and Midway. Some specimens in Core 318-2 (Plate 5, Figures 1-3) resemble the Bikini types (cf. $H$. curva Moebius), whereas others (Plate 6, Figures 2, 3, 4, right-hand specimen) have a slightly more open spiral, similar to that of the Midway specimens (Cole, 1969). Those in the Miocene Core 31810 (Plate 7, Figure 1) may also belong here. The more delicately built form with incomplete septula shown on Plate 6, Figure 1 is a different species. In the Eocene
Core 318-19, we find another group which is close to $H$. saipanensis Cole in its general habitus but has more (about nine) operculine chambers (Plate 8, Figures 1-3).

Lepidocyclina s.l.: Two fragments of a fairly large species occur in the lower Miocene Core 318-10 (Plate 7, Figures 2, 3).

Nummulites: Representatives of a small, striated, lenticular Nummulites species are found in the Eocene Cores 318-18 and 318-19 (Plate 7, Figures 10-12; Plate 8, Figures $7,8,10,11)$. They have longer chambers than the widespread $N$. pangaronensis Verbeek and might rather be related to the $N$. variolarius group. A more inflated Nummulites? species is figured on Plate 8, Figures 6 and 9.

\section{AGE OF THE SAMPLES AND OF THE DISPLACED FOSSILS}

According to the paleocorrelation chart prepared by the shipboard paleontologists, the nine cores containing shallow-water components have the following ages:

$\begin{array}{lll}\text { Site 315 (Hole 315A), } & \text { Core 9: } & \text { Oligocene } \\ & \text { Core 10: } & \text { Oligocene } \\ & \text { Core 17: } & \text { Maestrichtian } \\ \text { Site 316, } & \text { Core 27: } & \text { Campanian } \\ \text { Site 318, } & \text { Core 2: } & \text { Plio/Pleistocene } \\ & \text { Core 10: } & \text { Early Miocene } \\ & \text { Core 18: } & \text { Late Eocene } \\ & \text { Core 19: } & \text { Late Eocene } \\ & \text { Core 26: } & \text { Middle Eocene }\end{array}$

It has already been mentioned that the two Oligocene cores of Hole 315A are the only ones where the larger foraminifers and other displaced fossils are definitely reworked from older rocks. In these two cores, as well as in Cores 315A-17 and 316-27, these fossils are of Late Cretaceous (Campanian-Maestrichtian) age. The associations of larger foraminifers include Sulcoperculina, Pseudorbitoides, Asterorbis, and Lepidorbitoides? and are of a distinctive type known mainly from Central America. One species, Pseudorbitoides israelskyi, is usually confined to the Campanian (Brönnimann, 1957). It is found in Core 316-27 and probably also in Core 315A9. If we assume that the ages of these fossils are the same in America and in the Pacific, then we can state that the oldest shallow-water components at these sites are Campanian in age.

In the Tertiary of Site 318 , we have a greater variety of larger foraminifer associations: HeterosteginaAmphistegina in the Plio-Pleistocene, HeterosteginaLepidocyclina in the Miocene, and Asterocyclina-Nummulites-Heterostegina in the Eocene. These associations are not in obvious conflict with the ages of the respective samples, although some, particularly that of Core $318-19$, have a rather heterogeneous aspect. It is true that some of the larger foraminifers described here are not good age indicators, either because they are not specifically determined, or because they have a long stratigraphic range (Heterostegina suborbicularis can be found from late Eocene to Recent according to Cole, 1969).

\section{PALEOECOLOGICAL INTERPRETATION}

The particular combination of sedimentary and paleontological features observed in some cores during the drilling operations led the shipboard scientists to 
conclude that they were dealing with rocks containing shallow-water particles redeposited in deeper water. The present review of the paleontological evidence has certainly confirmed this conclusion.

The most common components of shallow-water origin are larger foraminifers (pseudorbitoids, discocyclinids, Amphistegina, Heterostegina, Nummulites, Sulcoperculina), bryozoans, and mollusk shell fragments). The minor constituents include corallinacean algae, coral fragments, small pieces of rudistids, and echinoid remains. This list shows that there are no components which would indicate a back-reef or lagoonal environment (such as peneroplid foraminifers, Halimeda, and dasycladacean algae). There are few true reef indicators, even if one includes all the coral fragments in this category. These are most common in Core 318-19 (Eocene), but some are also found in Core 318-2 (PlioPleistocene). The small pieces of corallinacean algae in the Eocene (Core 318-26) and the Cretaceous (Core $315 \mathrm{~A}-17)$ suggest either a reef-front or shallow-shelf (fore-reef) environment. Some of the more common larger foraminifers (Amphistegina, Heterostegina) are rather typical of the upper shelf in modern seas, at depths of less than 100 meters (Emery et al., 1954). The same applies to the bryozoans. Margaretta gracilior, for instance was recorded by the Siboga expedition in Indonesia from depths between 0 and 57 meters (R. Lagaaij, personal communication). The Eocene discocyclinids (Cores 318-18 and 318-26) probably also lived on the open shelf, in water rather deeper than most of the other larger foraminifers of that time (Kemper, 1966). The nummulitids presumably had their habitat close to, or in front of bars or reefs (Arni, 1965). Interpretation of the Cretaceous associations is more difficult, because of the absence of closely related modern counterparts. However, their composition does not appear to be substantially different from that in the Tertiary, with Pseudorbitoides, Sulcoperculina, and Asterorbis as some of the principal components.

Combining the evidence above, we can conclude that the shallow-water fossils of Sites 315,316 , and 318 generally lived on an open shelf in fairly warm, shallow water at a depth between the shore and rather less than 100 meters. These conclusions are similar to those of Burckle and Saito (1966), which were based on dredge hauls of Eocene rocks from the Tuamotu area in depths of 25 to 40 fathoms.

\section{ACKNOWLEDGMENTS}

I wish to thank the Chief Scientists of the Leg 33 cruise for their permission to study this material and to include this arti- cle in the Initial Reports volume. K.R. Kelts, Leg 33 participant, kindly gave me the samples and all the necessary shipboard data. To R. Lagaaij and A.J. Keij (Rijswijk, the Netherlands) I am most grateful for their help in evaluating and determining the bryozoan and coral fragments.

\section{REFERENCES}

Adams, C.G., 1970. A reconsideration of the East Indian letter classification of the Tertiary. Bull. British Mus. (Nat. Hist.), Geol., v. 19, p. 85.

American Museum of Natural History, 1966. Catalog of index foraminifera: 3 vols.

Arni, P., 1965. L'évolution des Nummulitinae en tant que facteur de modification des dépots littoraux: Mém. Bur. Rech. Géol. Min., Paris, v. 32, p. 7.

Brönnimann, P., 1957. Morphology and stratigraphic significance of Pseudorbitoides israelskyi Vaughan \& Cole: Ecolog. Geol. Helv., v. 50, p. 582.

Burckle, L.H. and Saito, T., 1966. An Eocene dredge haul from the Tuamotu Ridge: Deep-Sea Res., v. 13, p. 1207.

Cole, W.S., 1954. Larger foraminifera and smaller diagnostic foraminifera from Bikini drill holes: U.S. Geol. Survey, prof. Paper 260-0, p. 569. , 1957a. Geology of Saipan, Marshall Islands, Part 3, paleontology. larger foraminifera: U.S. Geol. Survey, Prof. P. 280-I, p. 321.

1957b. Larger foraminifera from Eniwetok Atoll drill holes: U.S. Geol. Survey, Prof. P. 260-V, p. 743. 1959. Asterocyclina from a Pacific seamount: Contrib. Cushman Found. Foram. Res., v. 10, p. 10. 1963. Tertiary larger foraminifera from Guam: U.S. Geol. Survey, Prof. P. 403-E, p. 28.

1969. Larger foraminifera from deep drill holes on Midway atoll: U.S. Geol. Survey, Prof. P. 680-C, p. 1-13.

Dilley, F.C., 1973. Cretaceous larger foraminifera. In Hallam, A. (Ed.), Atlas of palaeobiogeography: New York (Elsevier), p. 403.

Emery, K.O., Tracey, J.I., Jr., and Ladd, H.S., 1954. Geology of Bikini and nearby atolls. Part 1, geology: U.S. Geol. Survey, Prof. P. 260-A, p. 1-269.

Glaessner, M.F., 1960. Upper Cretaceous larger foraminifera from New Guinea: Sci, Rep., Tohoku Univ., 2d ser., v. 4, p. 37.

Harland, W.B. et al. (Eds.), 1967. The fossil record: Geol. Soc. London.

Kemper, E., 1966. Beobachtungen an oberozänen Riffen des Ergene-Beckens (Türkisch-Thrazien): N. Jb. Geol. Pal., Abh., v. 125 , p. 540

Winterer, E.L., Ewing, J.I., et al., 1973. Initial Reports of the Deep Sea Drilling Project, Volume 17: Washington (U.S. Government Printing Office). 



\section{PLATE 1}

All specimens are from Sample 315A-9, CC.

Figures 1, 2, 4-6, 8, and 9 represent thin sections of free specimens.

Figures 1, 2, $4 \quad$ Pseudorbitoides cf. israelskyi Vaughan and Cole.

1. Cross-section, $70 \times$.

2. Equatorial section, $70 \times$. Radial plates are weakly visible along the upper margin.

4. Equatorial section showing the periembryonic spiral chambers and traces of the radial plates (at the upper margin), $28 \times$.

Figures 3, 5, 6 Asterorbis cf. havanensis Palmer.

3. Surface view of a free specimen, $25 \times$.

5. Equatorial section, $70 \times$.

6. Cross-section, $70 \times$.

Figure $7 \quad$ Undetermined cylindrical objects, $12 \times$.

Figures 8,9 Sulcoperculina vermunti Thiadens.

8. Equatorial section, $28 \times$.

9. Cross-section, $70 \times$. 
PLATE 1

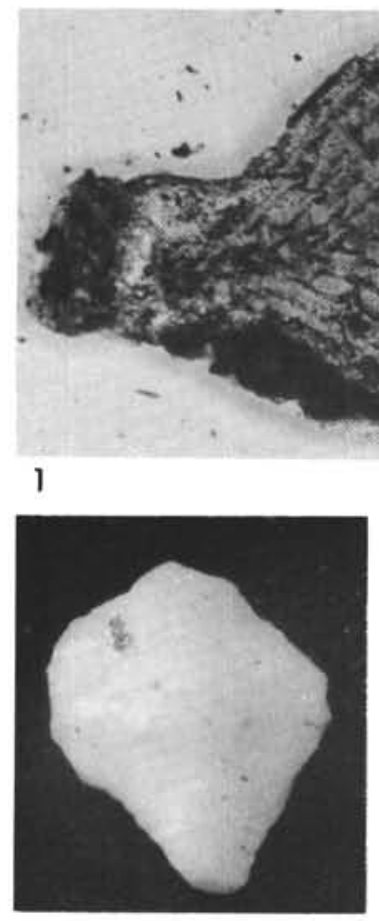

3

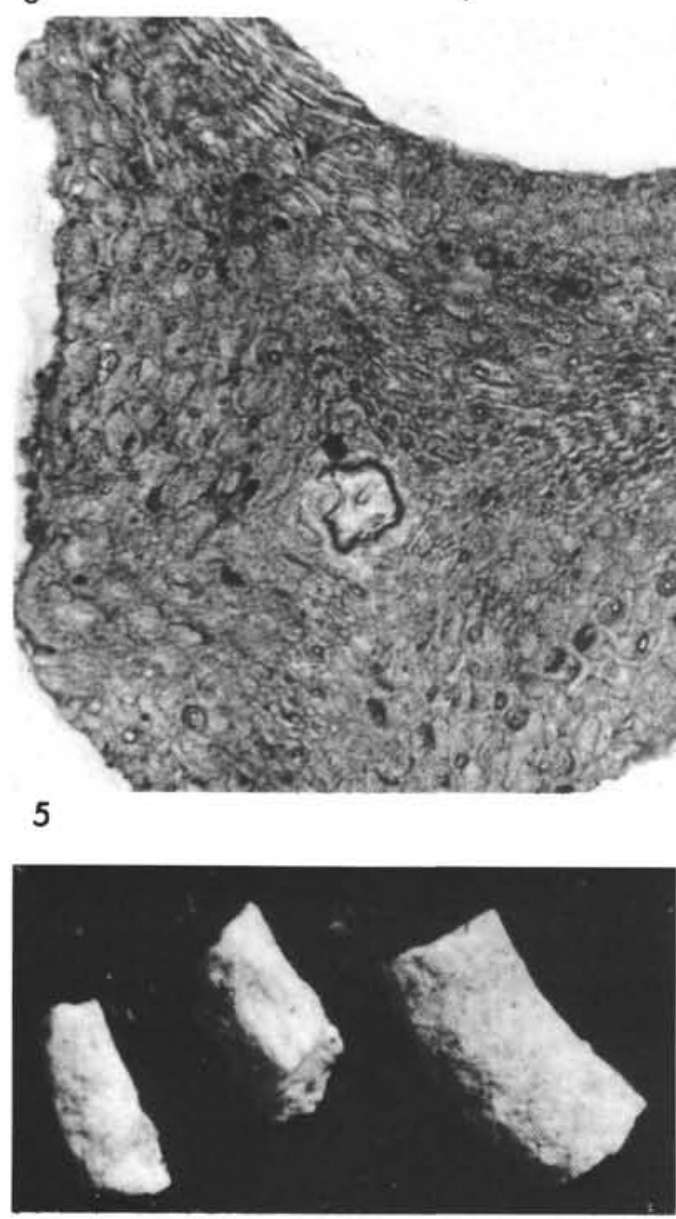

7

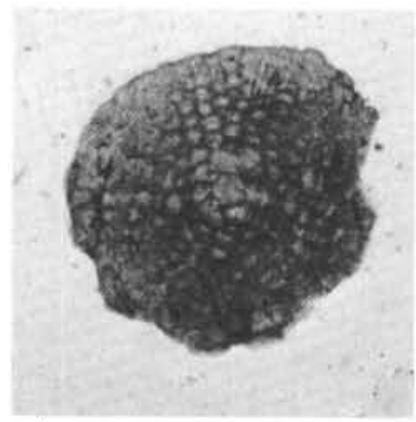

4

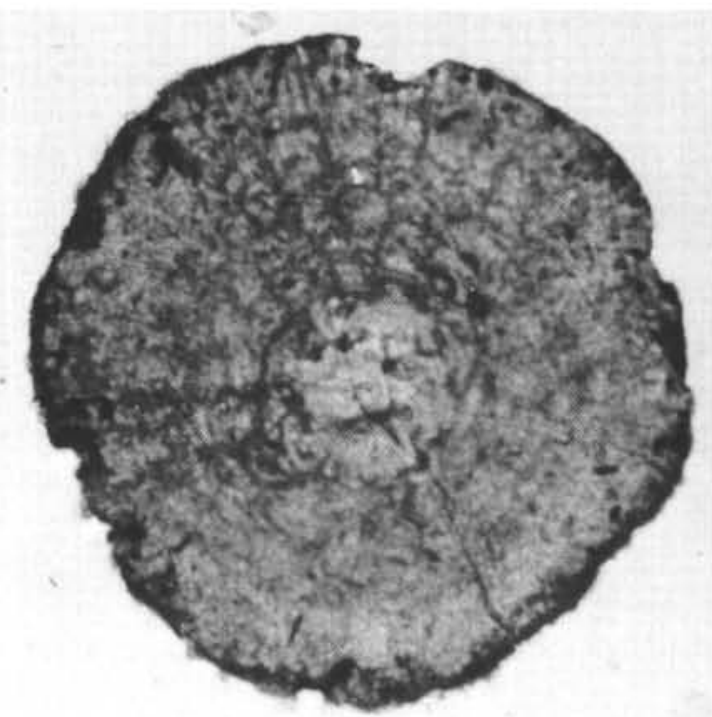

2

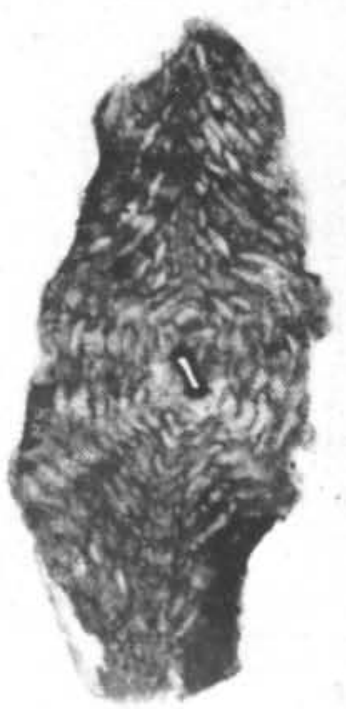

6

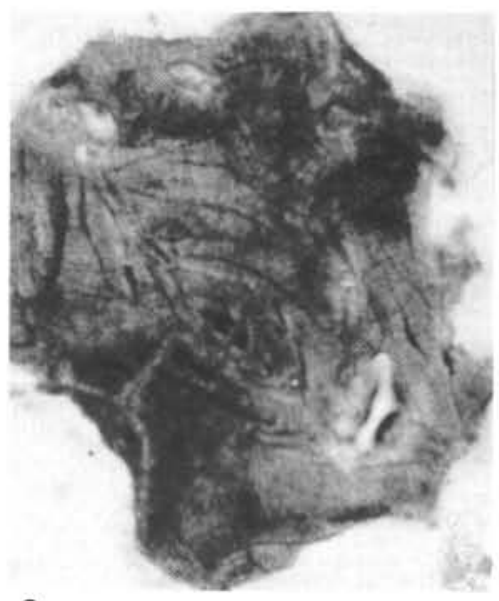

9 


\section{PLATE 2}

All specimens are random thin sections of a hard limestone from Sample 315A-10-3, 134-135 cm.

Figures 1, $3 \quad$ Pseudorbitoides? sp.

1. Oblique cross-section, $70 \times$.

3. Cross-section, $75 \times$.

Figures 2, $4 \quad$ Asterorbis sp.

2. Cross-section, $75 \times$. 4. Oblique cross-section, $28 \times$.

Figures 5, 11 Globotruncana spp. Two cross-sections, 78×. Associated are shell fragments of Tertiary globigerinids.

Figure $6 \quad$ Globorotalia? sp., $78 \times$.

Figures 7, 8 Lepidorbitoides? sp. Two cross-sections, $28 \times$.

Figures 9,10 Sulcoperculina vermunti Thiadens.

9. Oblique equatorial section, $75 \times$.

10. Cross-section, $75 \times$. 
PLATE 2

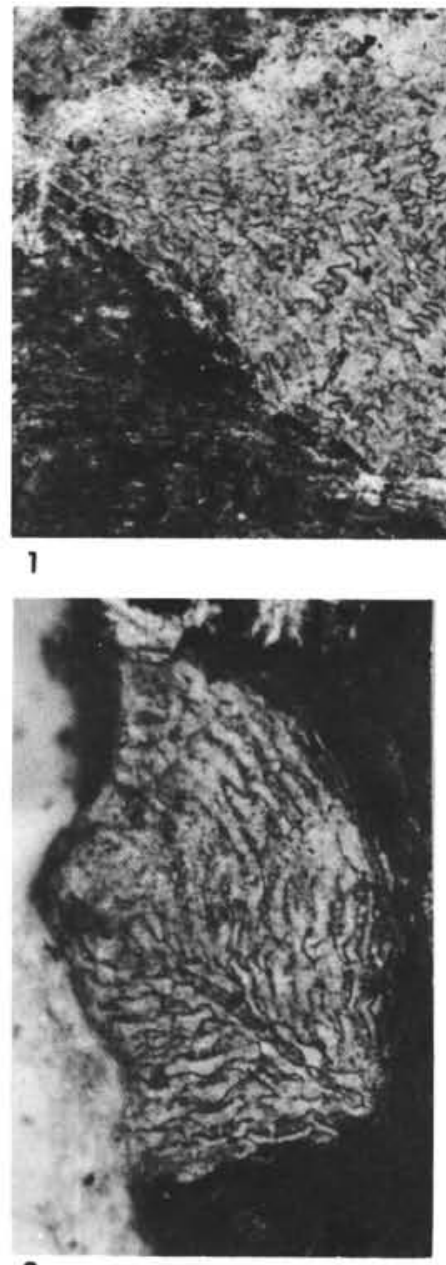

3

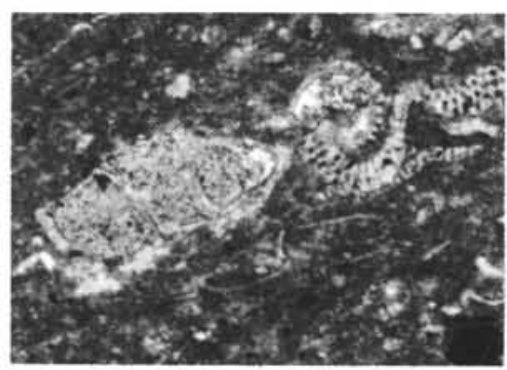

5

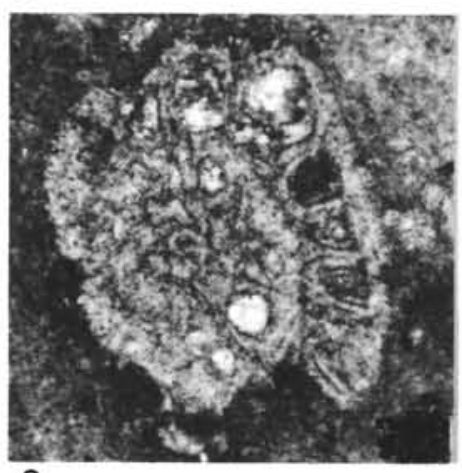

9

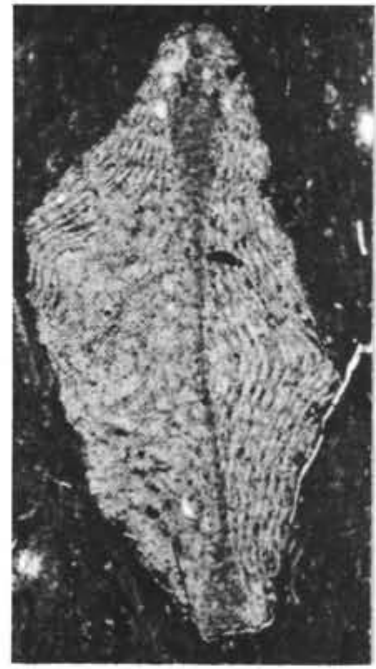

4

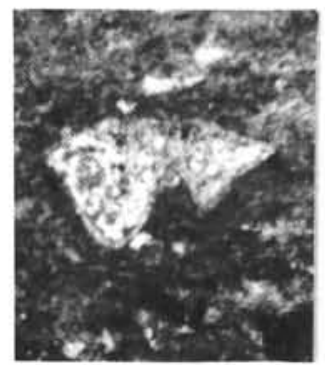

6

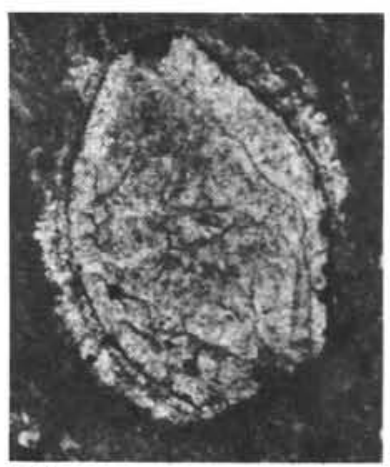

10

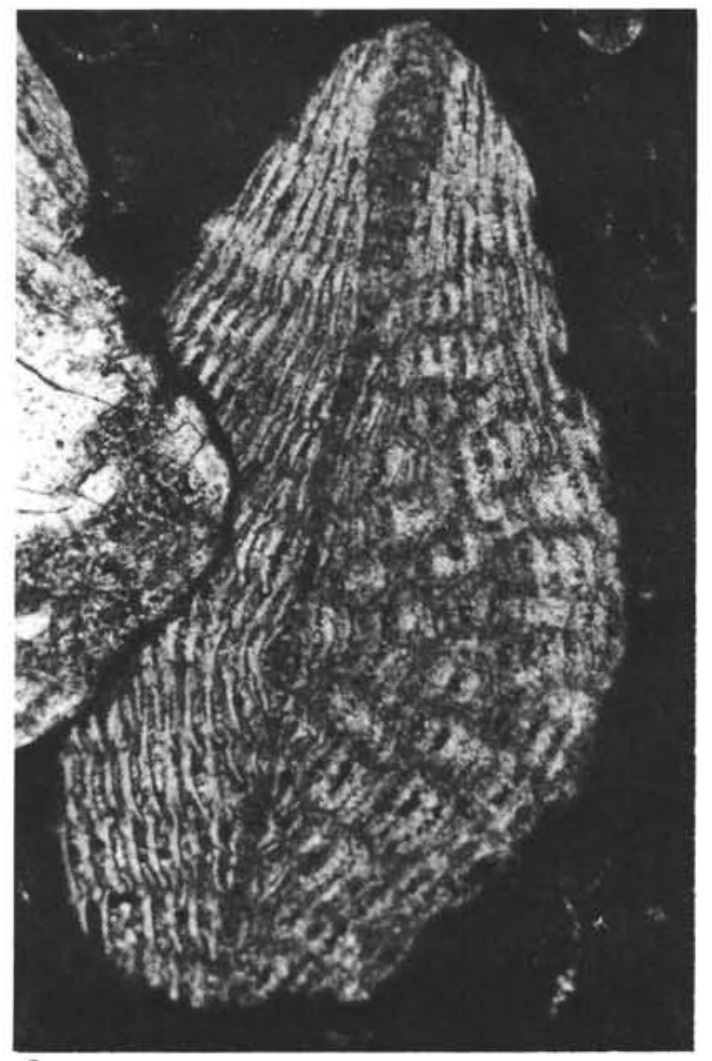

2

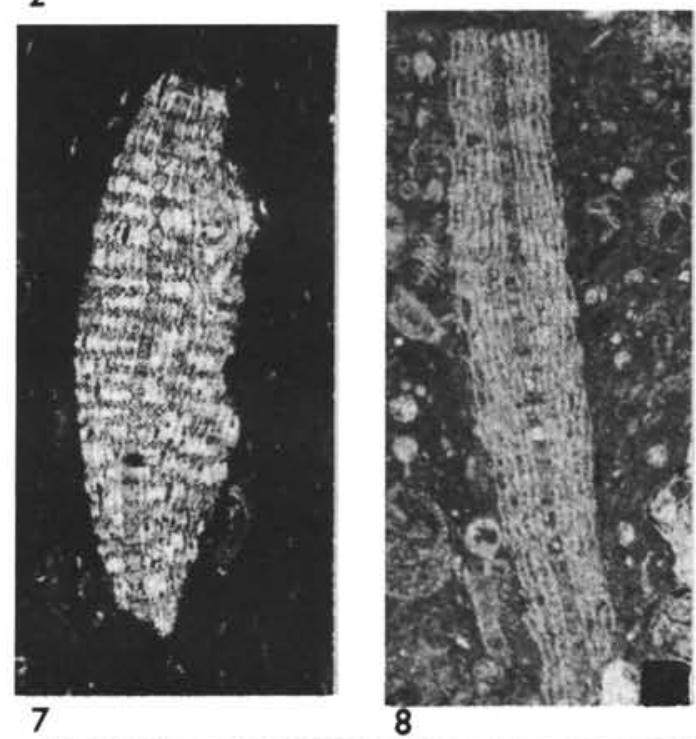

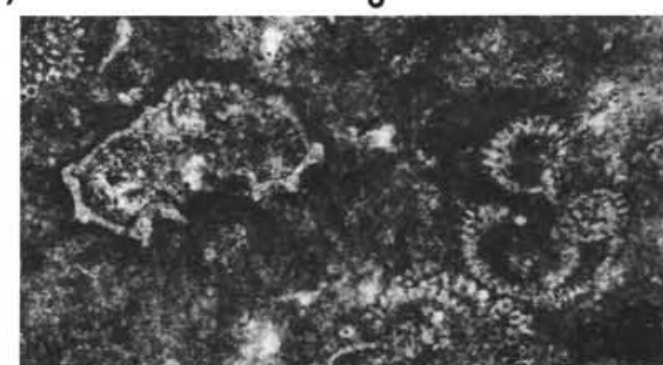
11 


\section{PLATE 3}

All photographs are random thin sections of specimens from hard limestone of Sample 315A-17-2,

112-114 cm (Figures 2-10) and 117-119 cm (Figure 1).

Figures 1,3,4,5 Cross-sections of undetermined representatives of the Family Pseudorbitoididae.

1. Approx. $60 \times$. (Print of a thin section kindly supplied by the shipboard party.)

$3,4,5,75 \times$.

Figure 2 Asterorbis? sp. Cross-section, $78 \times$.

Figures 6,7 Sulcoperculina vermunti Thiadens.

6. Oblique equatorial section, $75 \times$.

7. Two cross-sections, $75 \times$.

Figure 8 Haplophragmoides? sp. Equatorial section, $75 \times$.

Figures 9, 10 Small fragments of coralline algae, $75 \times$. 
PLATE 3

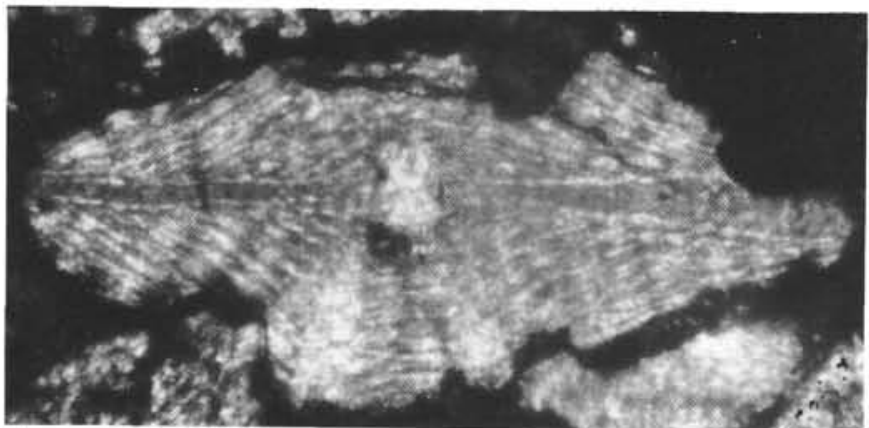

1
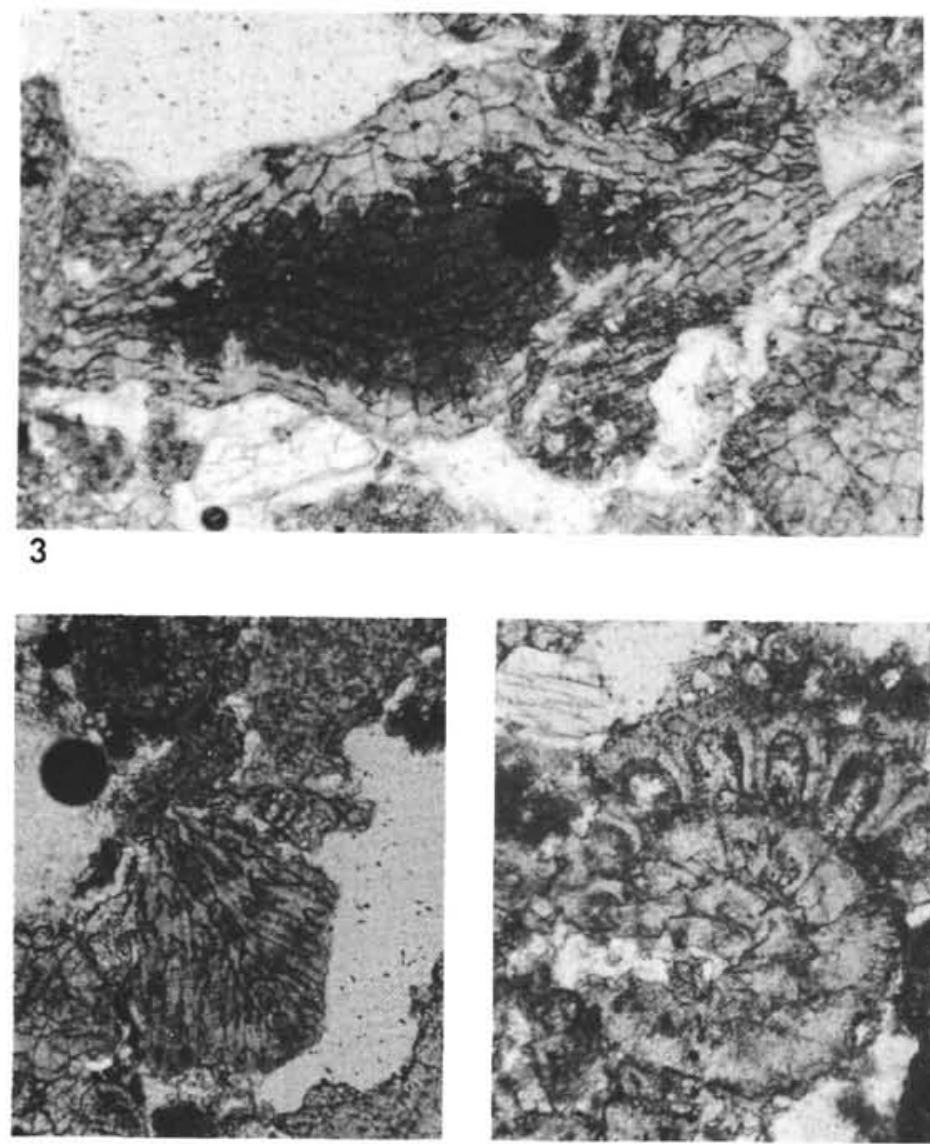

5

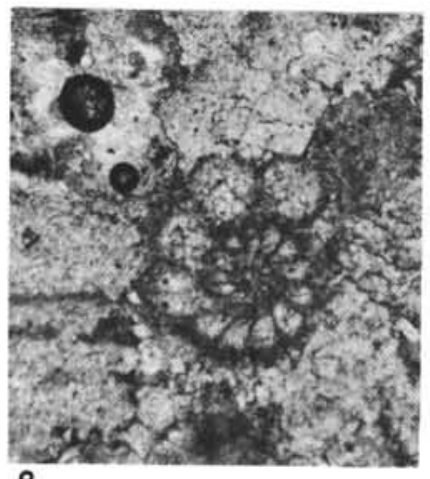

8

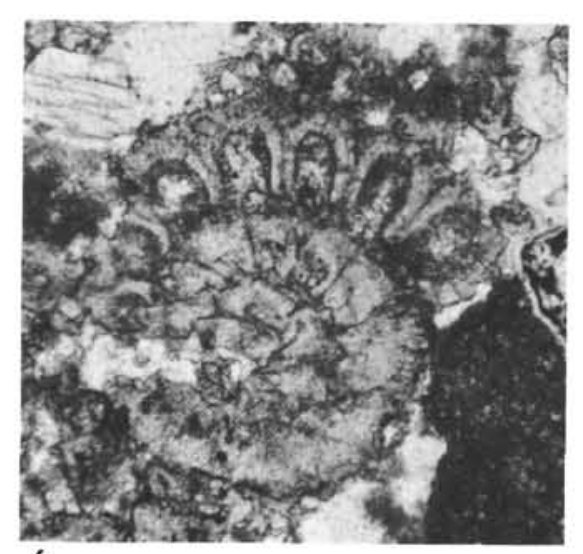

6

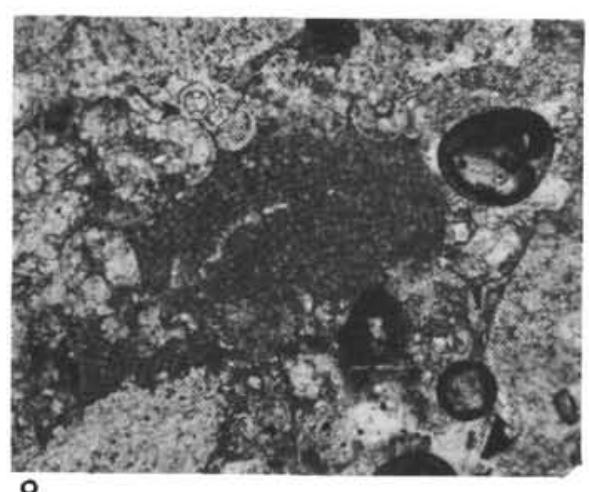

9
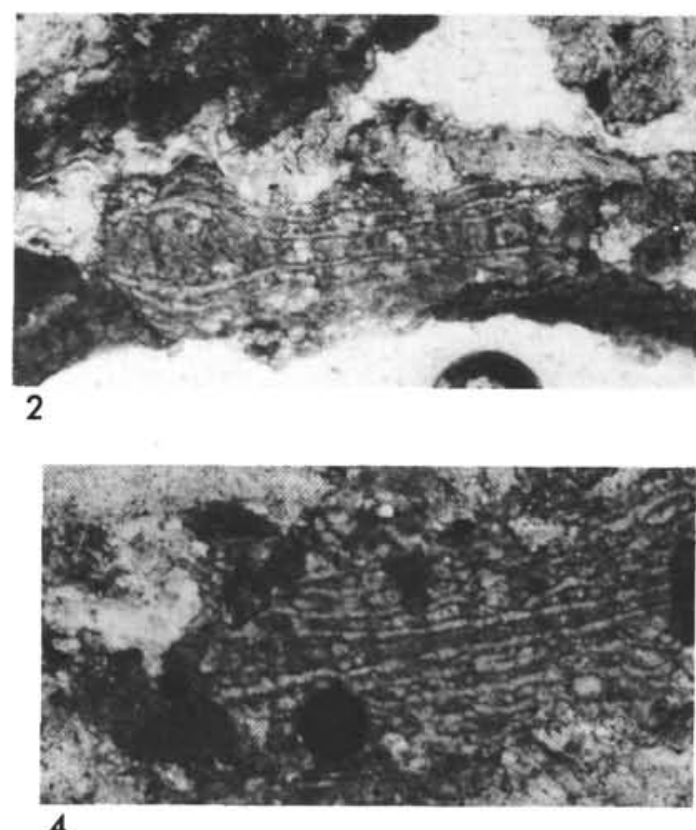

4
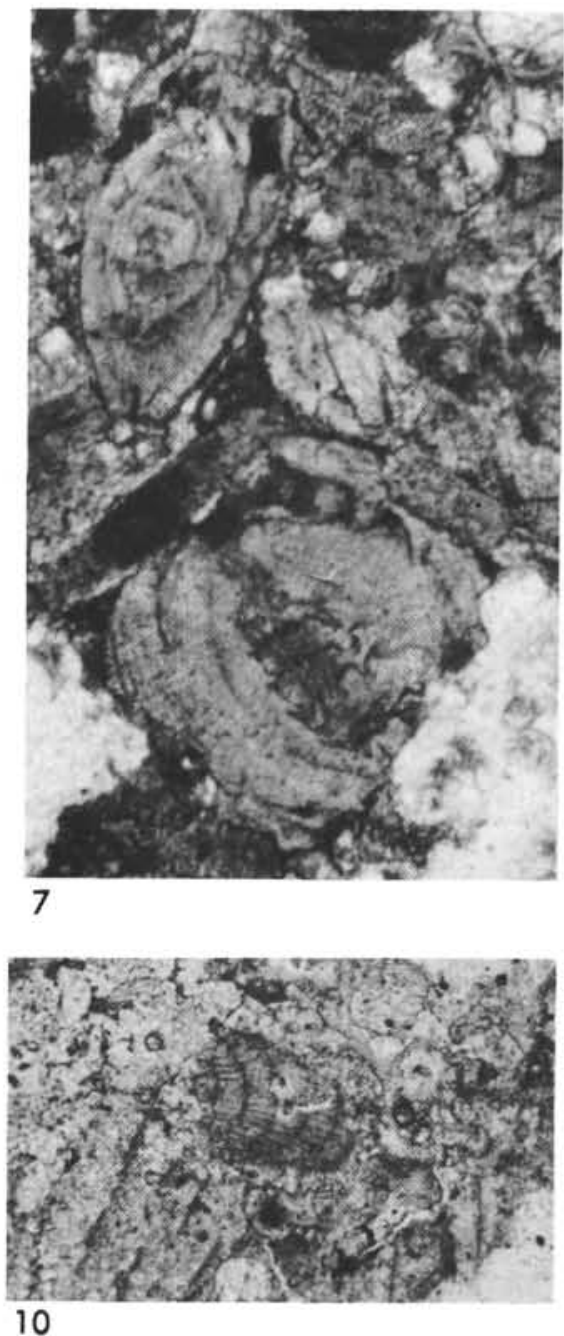


\section{PLATE 4}

Free specimens from the washed residue of Sample 316-27-3, 67-69 cm.

Figures 1-9 Pseudorbitoides israelskyi Vaughan and Cole.

1, 2. Free specimens, lateral view, $28 \times$.

3 . The same three specimens in peripheral view, $28 \times$.

4. Equatorial section, showing initial chamber, part of periembryonic spiral, and traces of the radial plates (left margin), $75 \times$.

5. Equatorial section showing periembryonic spiral, $85 \times$.

6. Near-equatorial section, showing radial plates (at top margin), $85 \times$.

7. Cross-section of a small specimen, similar to the ones shown on Figure 2, $75 \times$.

8. Cross-section of a larger specimen, $80 \times$.

9. Cross-section, with traces of the radial plates in the equatorial layer, $80 \times$. 
PLATE 4

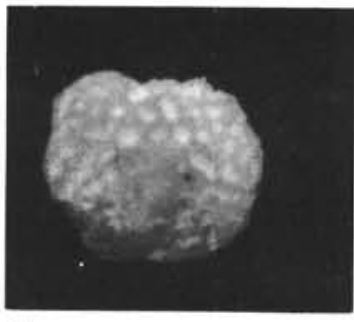

1

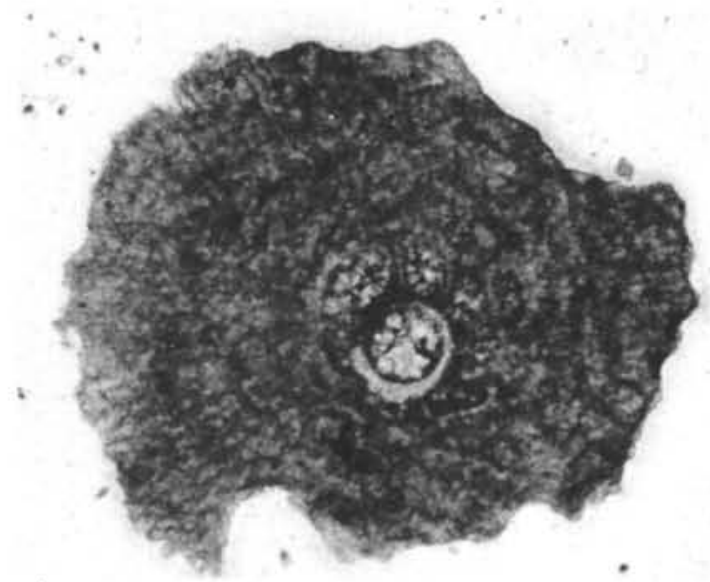

2

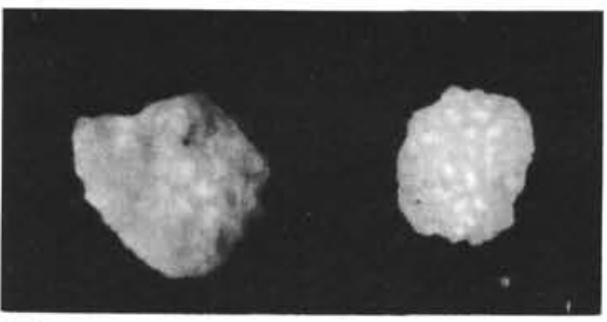

4

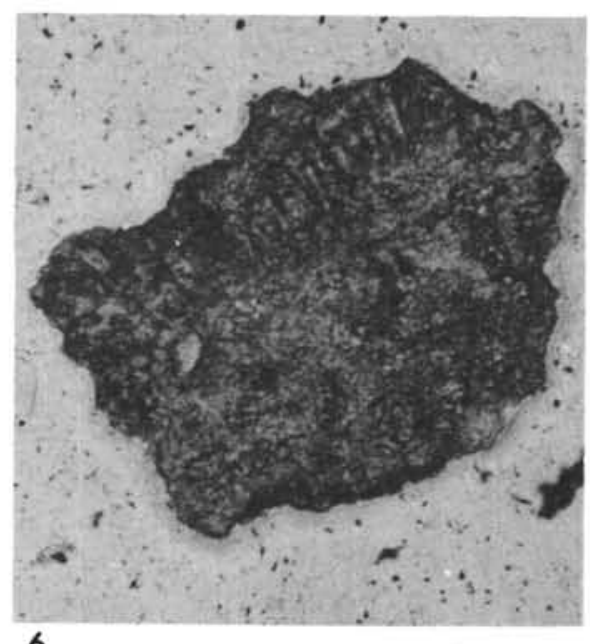

6

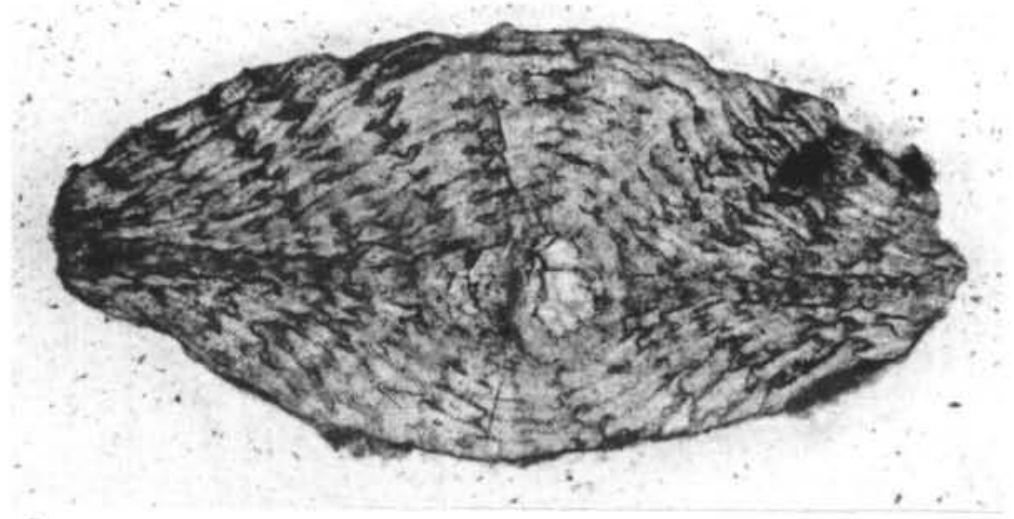

8

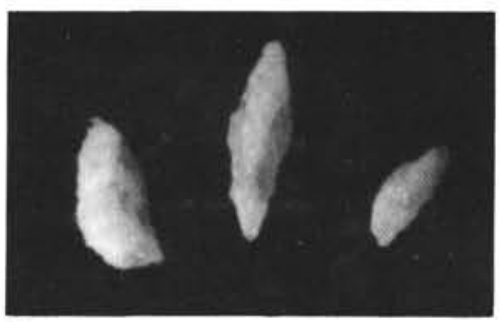

3

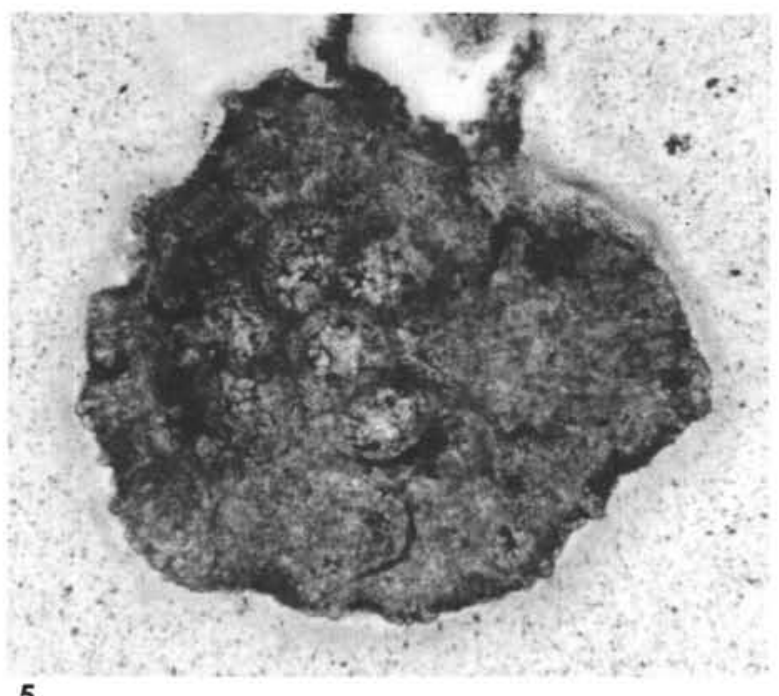

5

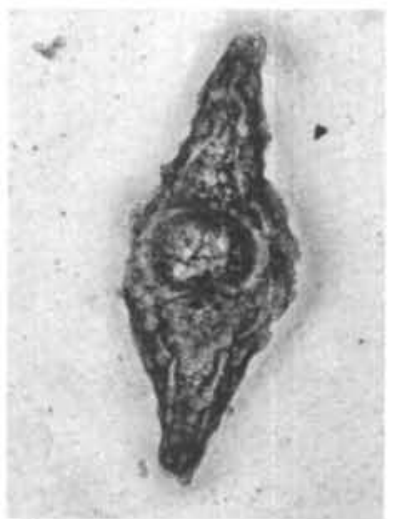

7

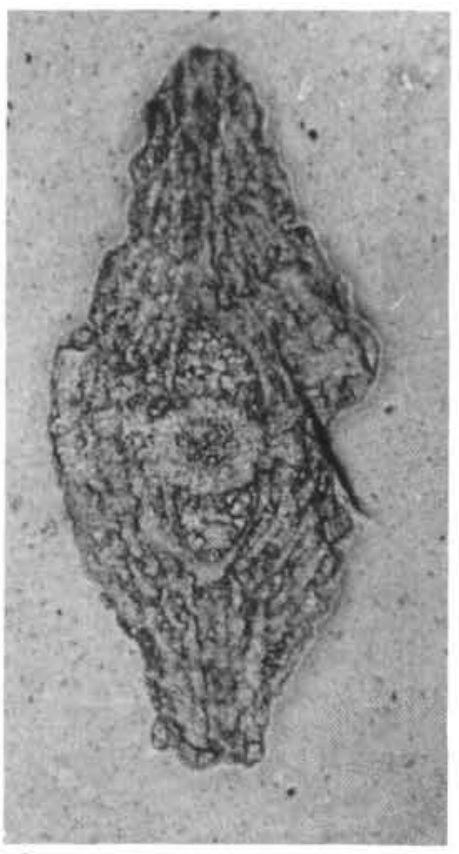

9 


\section{PLATE 5}

Free specimens from Sample 318-2-2, 15-17 cm.

Figures 1-3 Heterostegina suborbicularis d'Orbigny (after W.S. Cole).

1. Thin section through the equatorial plane, $34 \times$. 2, 3. Lateral and peripheral view of two free specimens, $14 \times$.

Figures 4,5 Amphistegina sp. indet. A. Free specimens in lateral and peripheral view, $14 \times$.

Figures 6,7 Amphistegina sp. indet. B. Free specimens in lateral and peripheral view, $14 \times$.

Figures 8,9 Amphistegina sp. indet. C. Free specimens in lateral and peripheral view, $14 \times$.

Figures 10,12 Coral? fragments.

10. Free specimens, 13×.

12. Thin section, $35 \times$.

Figure $11 \quad$ Fragment of a crab carapace? (left) and two fish otoliths (right), $13 \times$.

Figure 13 Fragments of bryozoans, 14×. Margaretta aff gracilior (Ortmann) (lower left), Idmonea spp. (specimens at upper right and third from left in lower row), and undetermined sertellids (second and fourth specimen in lower row). Det. R. Lagaaij. 
Plate 5
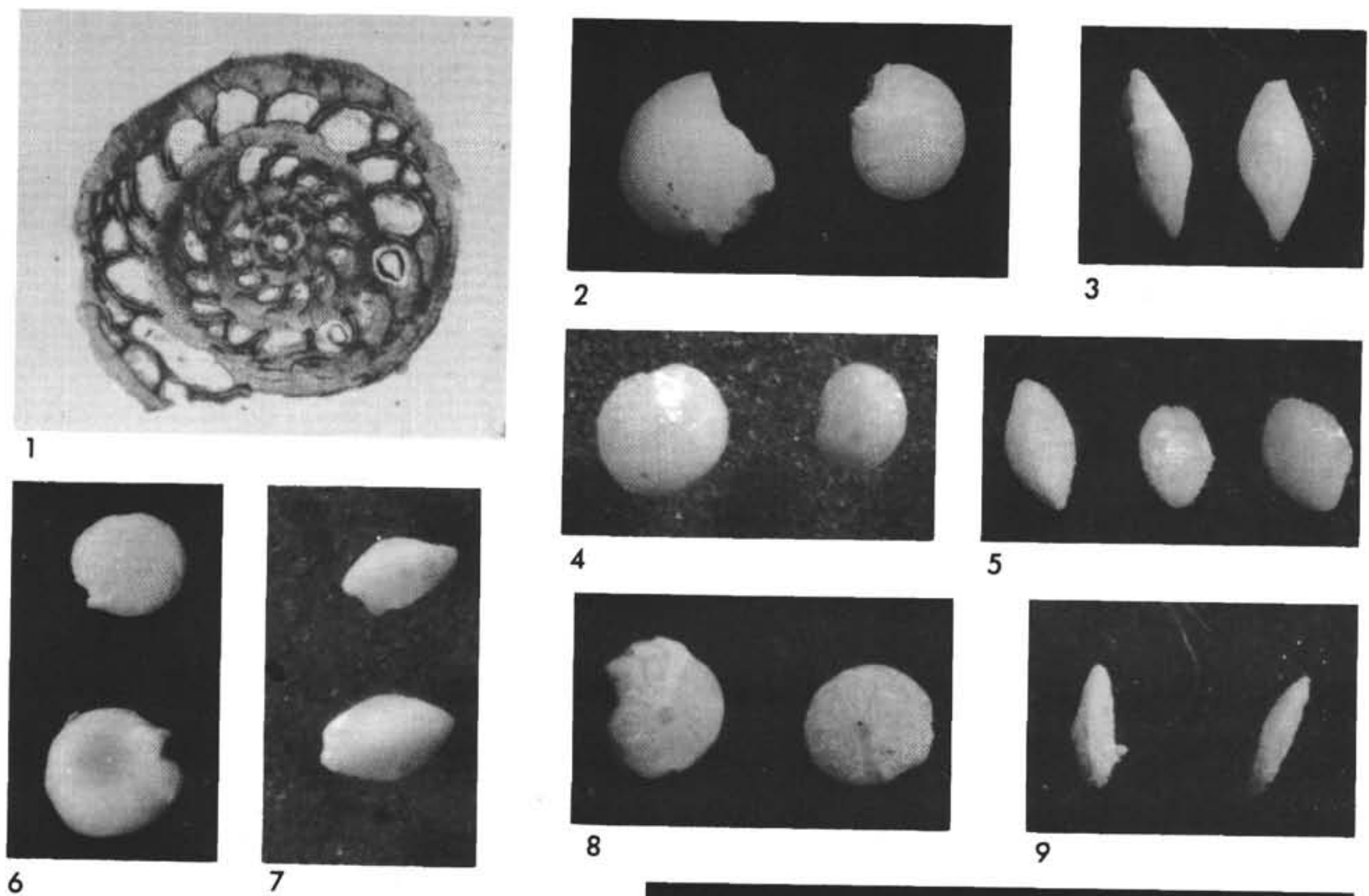

4
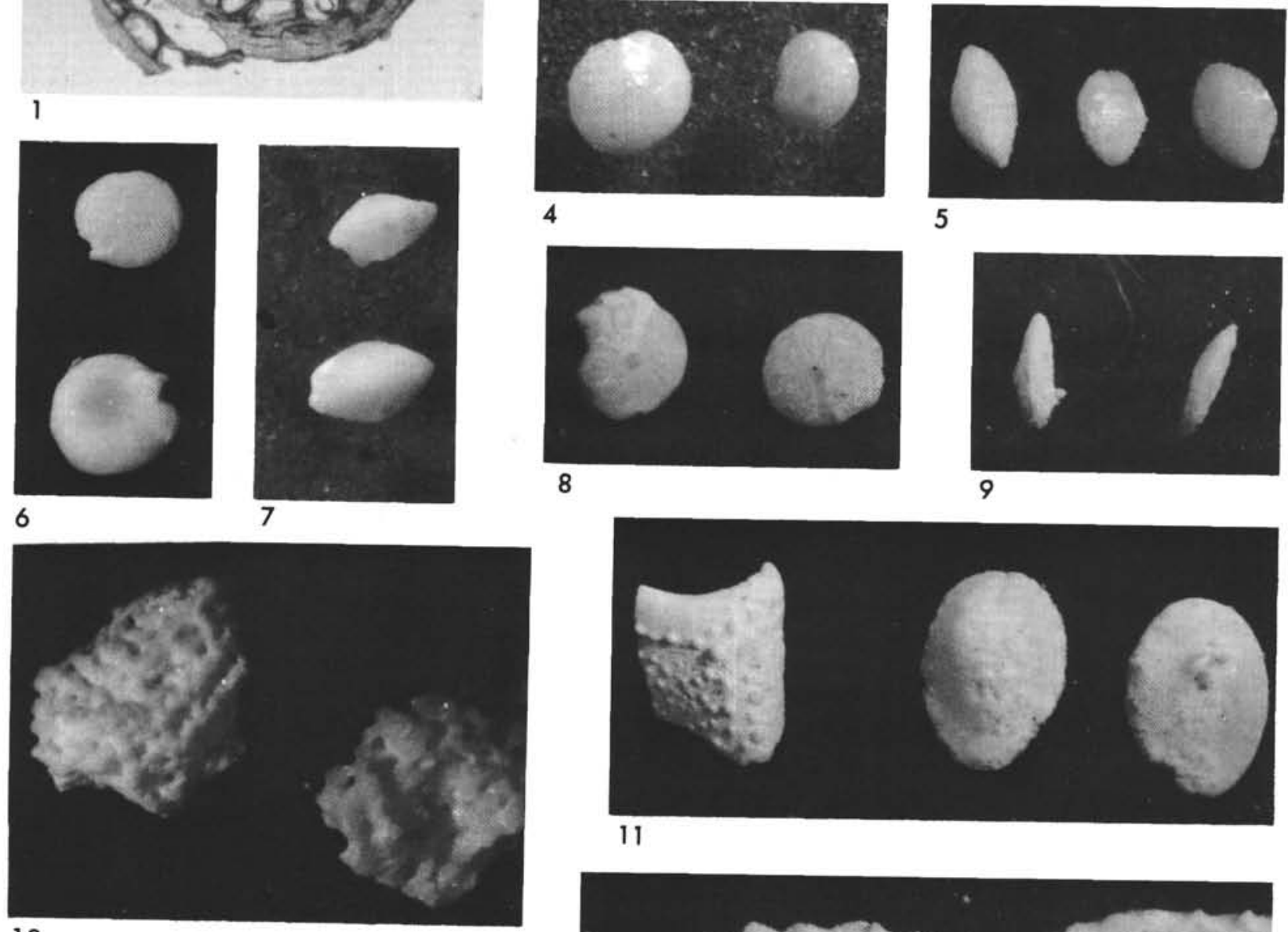

10
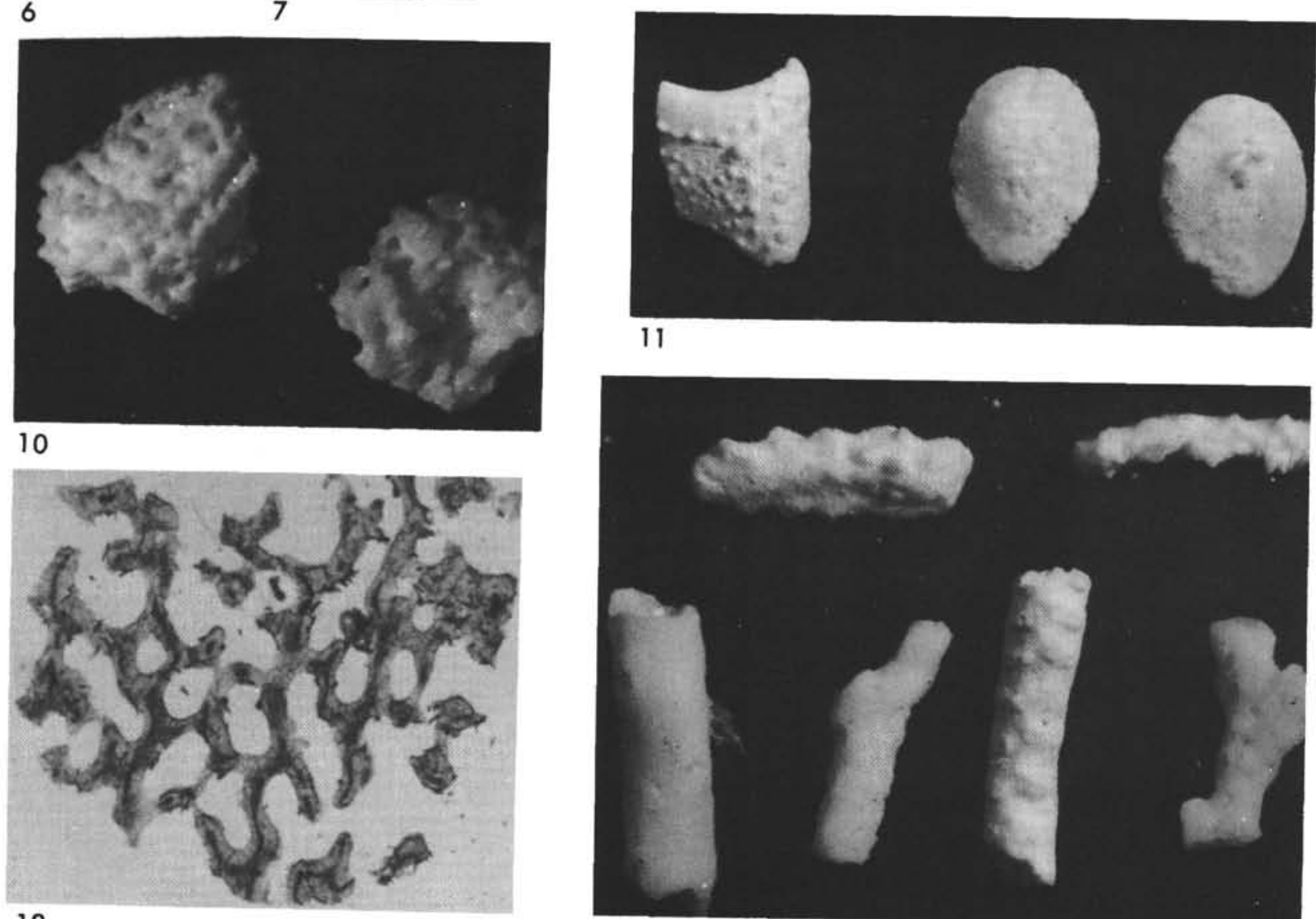

11

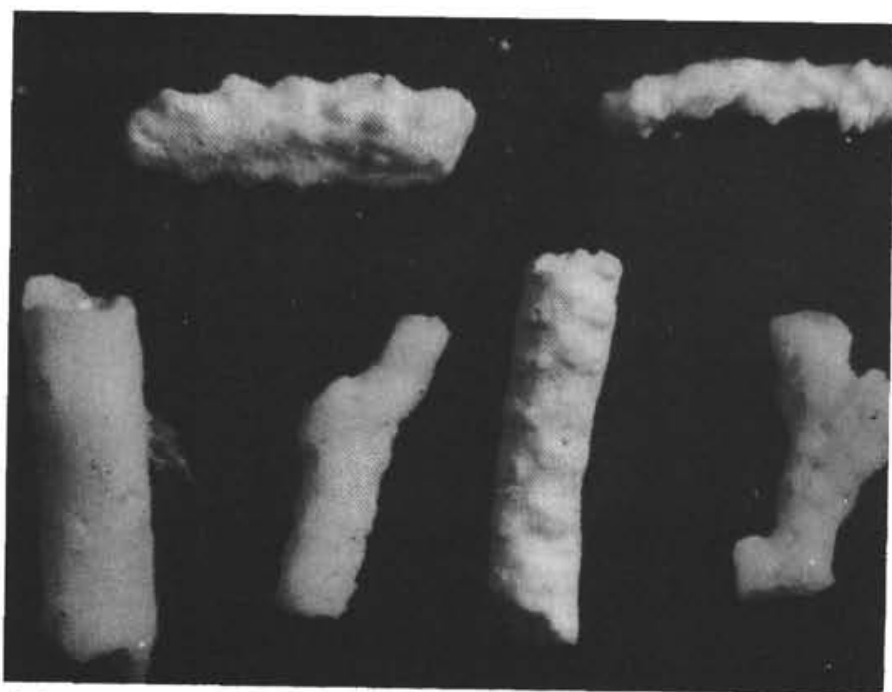




\section{PLATE 6}

Free specimens from washed residue of Sample 318-2, CC.

Figure $1 \quad$ Heterostegina sp. indet. A. View of the median plane of a polished specimen, $13 \times$.

Figures 2, $3 \quad$ Heterostegina cf. suborbicularis d'Orbigny.

2 . View of the median plane of a polished specimen, $13 \times$.

3. Thin section through the equatorial plane of another specimen, $13 \times$.

Figures 4, $5 \quad$ Heterostegina spp. Lateral and peripheral views of free specimens, $14 \times$.

Figures 6-8 Amphistegina? sp. indet. D.

6 , 7. Peripheral and lateral view of a free specimen, $13 x$.

8. View of the equatorial plane of a polished specimen, $30 \times$.

Figures 9-12 Amphistegina sp. indet B.

9. Thin section in the equatorial plane, $30 \times$.

10,11 . Peripheral and lateral views of free specimens, $13 \times$.

12. Axial thin section, $34 \times$. 
Plate 6

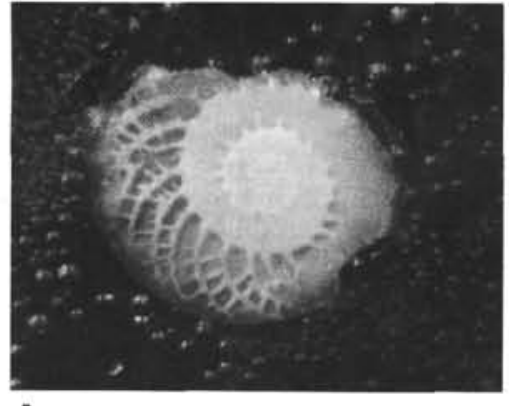

1

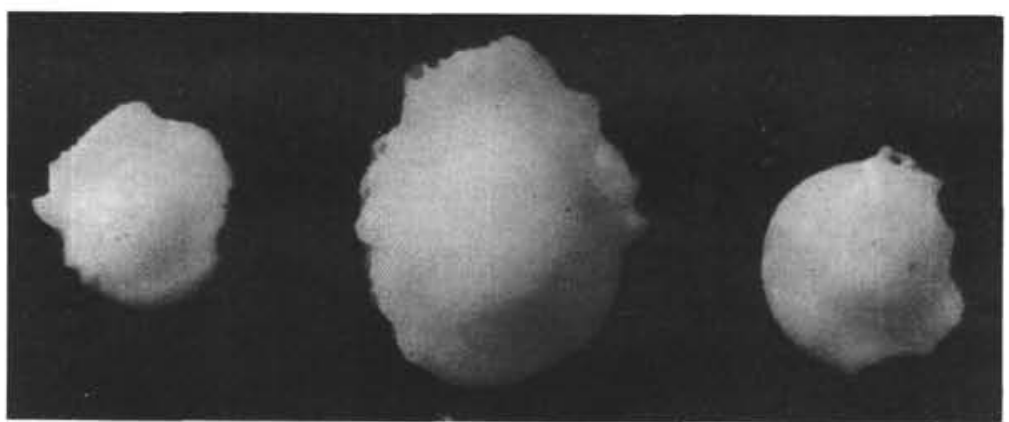

4

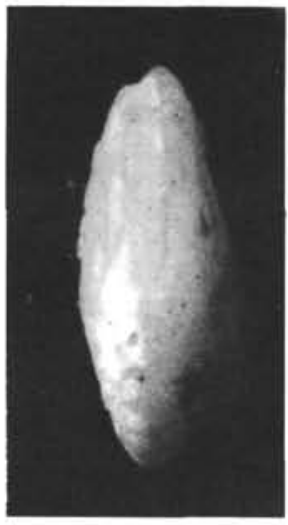

6

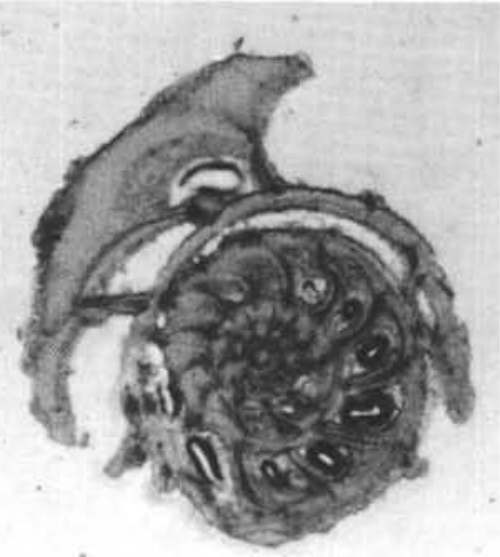

9

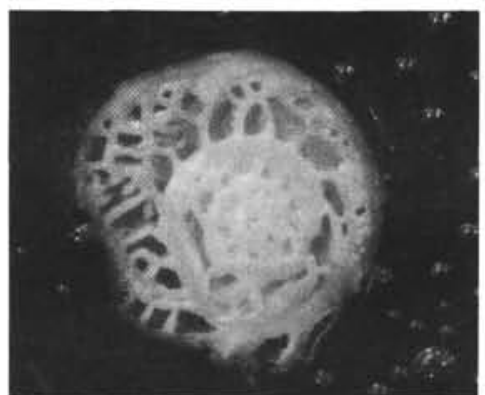

2

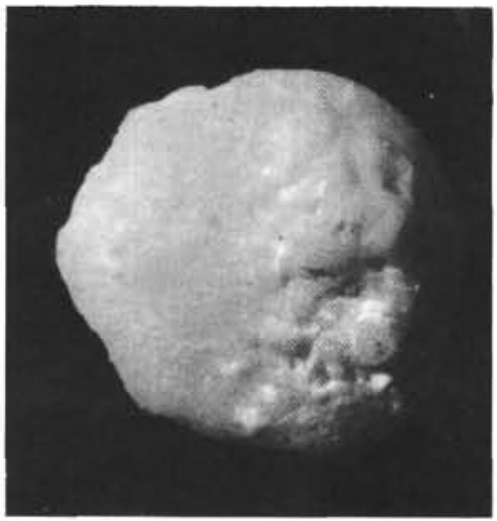

7

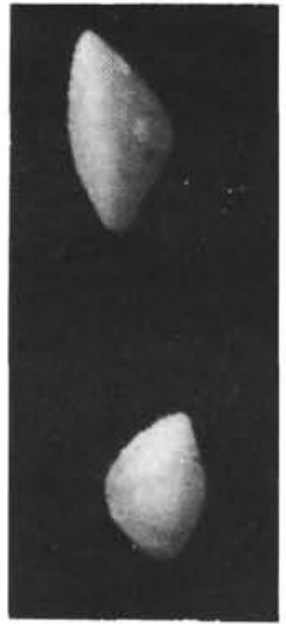

10

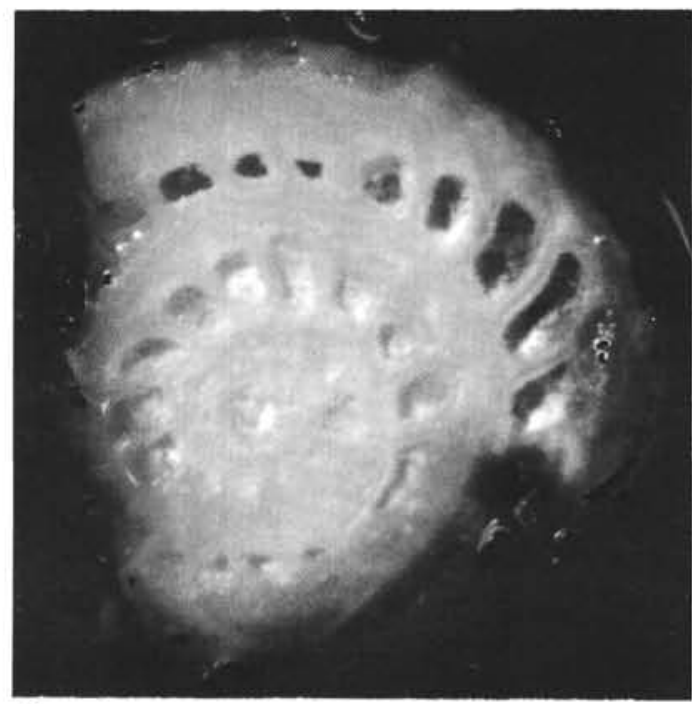

8

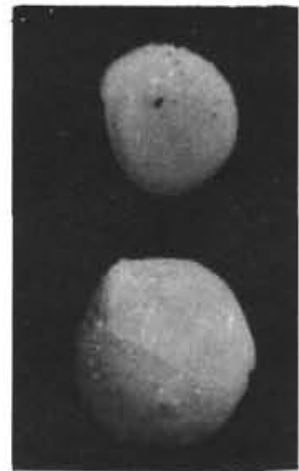

11

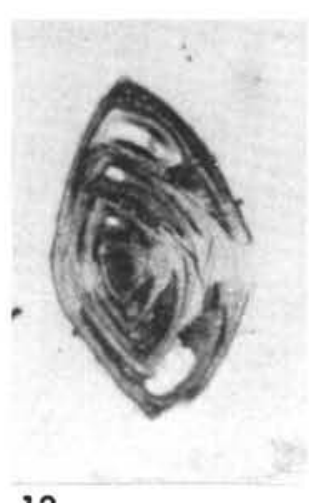

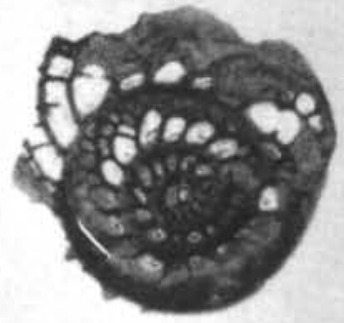

3

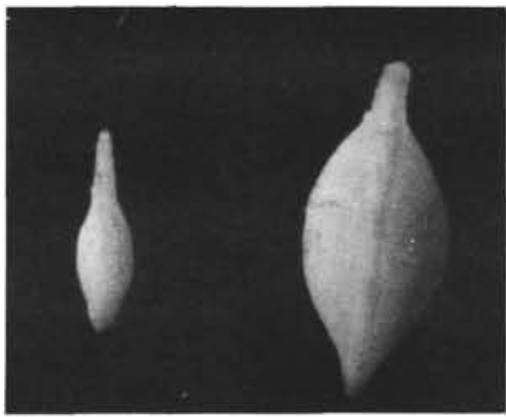

5 


\section{PLATE 7}

Specimens from Sample 318-10-1 (Figures 1-3) and from Sample 318-18-2, 45-49 cm (Figures 4-12)

Figure 1 Heterostegina sp. indet. B. (aff. H. suborbicularis d'Orbigny?). View of the equatorial plane of a polished specimen, $13 \times$.

Figures 2, $3 \quad$ Lepidocyclina s.l., sp. indet.

2. Thin section of a fragment across the equatorial plane, $13 \times$.

3. Detail of Figure 2, 70x.

Figures 4-6,9 Asterocyclina elongaticamera Cole.

4, 5. Free specimens in lateral and peripheral view, $15 \times$.

6. Thin section (cross-section), $34 \times$.

9. Equatorial thin section, $34 \times$.

Figures 7,8 Asterocyclina sp. indet.

7. Lateral view of a free specimen, $25 \times$.

8. Thin section through the equatorial plane, $34 \times$.

Figures 10-12 Nummulites sp., aff. $N$. variolarius (Lamarck).

10,11 . Peripheral and lateral view of free specimens, $25 \times$.

12. Thin section in the equatorial plane, $34 \times$. 
SHALLOW-WATER FORAMINIFERS AND ASSOCIATED MICROFOSSILS

PLATE 7

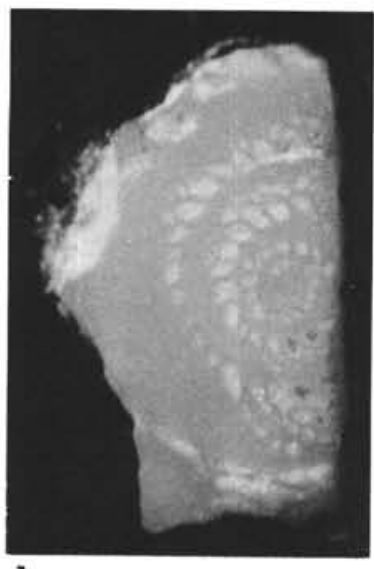

1

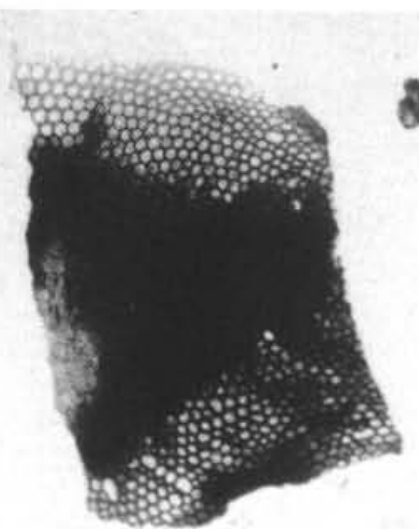

2

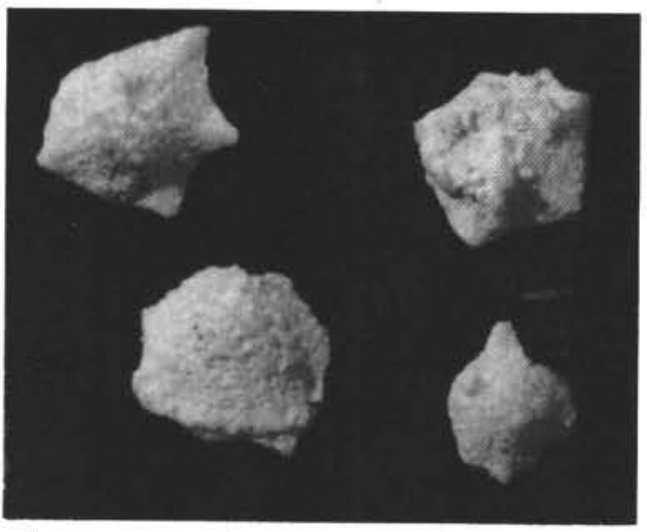

4

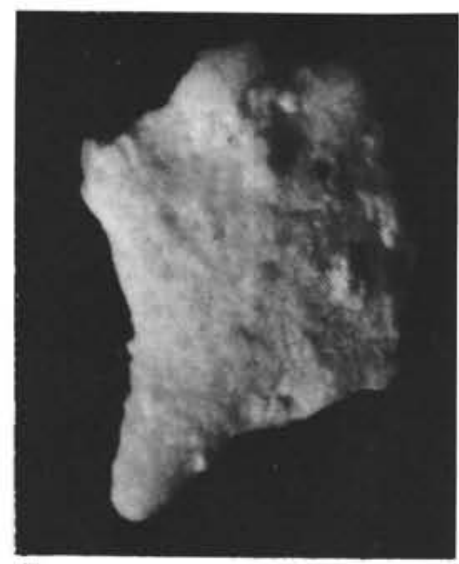

7

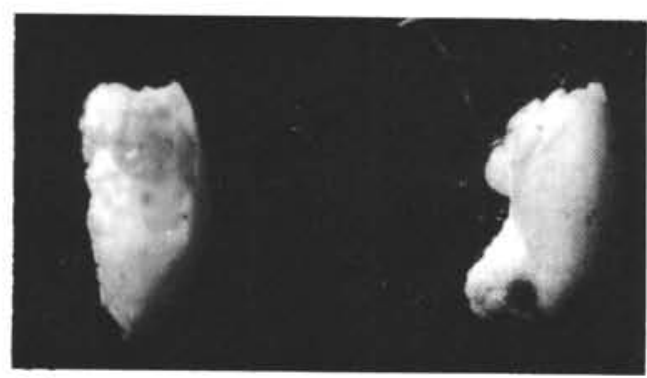

10

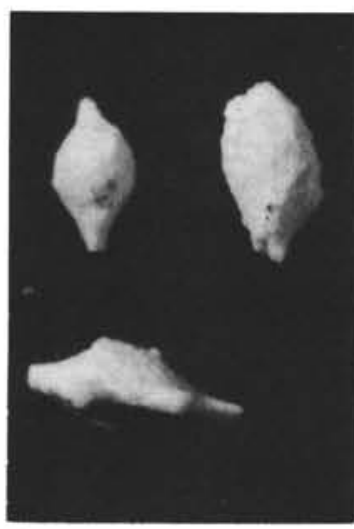

5

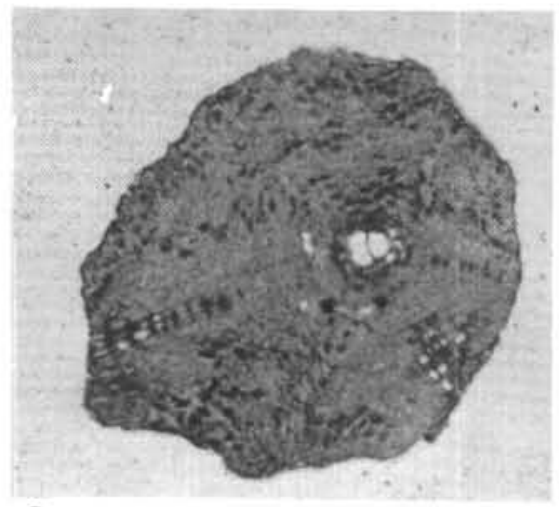

8

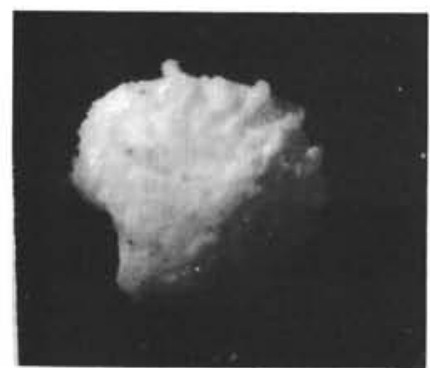

11

9

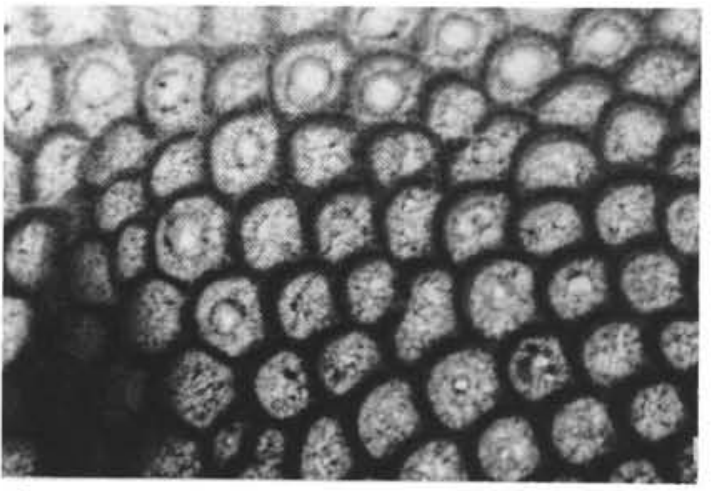

3

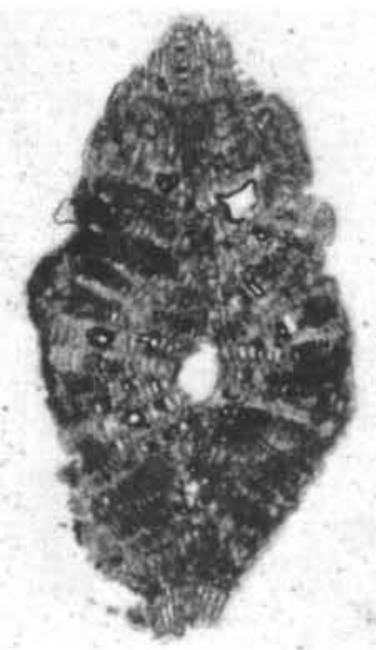

6
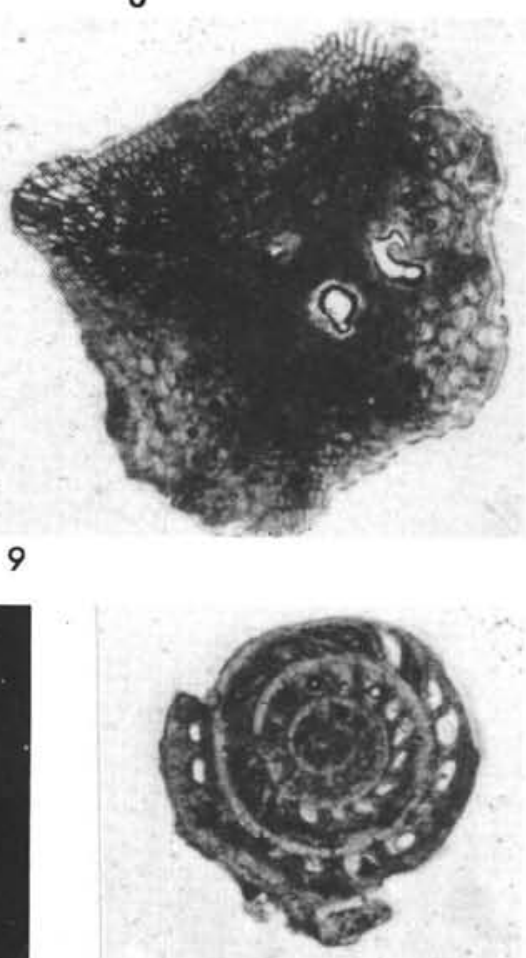

12 


\section{PLATE 8}

Free specimens from washed residue of Sample 318-19-2, $134-138 \mathrm{~cm}$ (see also Plate 9, Figure 1).

Figures 1-3 Heterostegina sp. indet. C.

1, 2. Peripheral and lateral views of free specimens, $14 \times$.

3. A polished section through the equatorial plane, $13 \times$.

Figures 4, 5 Cycloclypeus? sp.

4. Lateral view of a free specimen, $13 \times$.

5. Polished section of the equatorial plane of the same specimen, $23 \times$.

Figures 6,9 Nummulites? sp. indet.

6. Free specimen in peripheral view, $30 \times$ (this specimen was later used for preparing the thin section of Figure 9).

9. Axial thin section, $33 \times$.

Figures 7, 8, 10, Nummulites sp., aff. $N$. variolarius (Lamarck)?

11

7. Lateral view of a complete specimen, $27 \times$.

8. Two specimens in peripheral view, $22 \times$.

10. Polished section through the equatorial plane, $33 \times$.

11. Thin section of the specimen in Figure 10, $35 \times$. 
PLATE 8
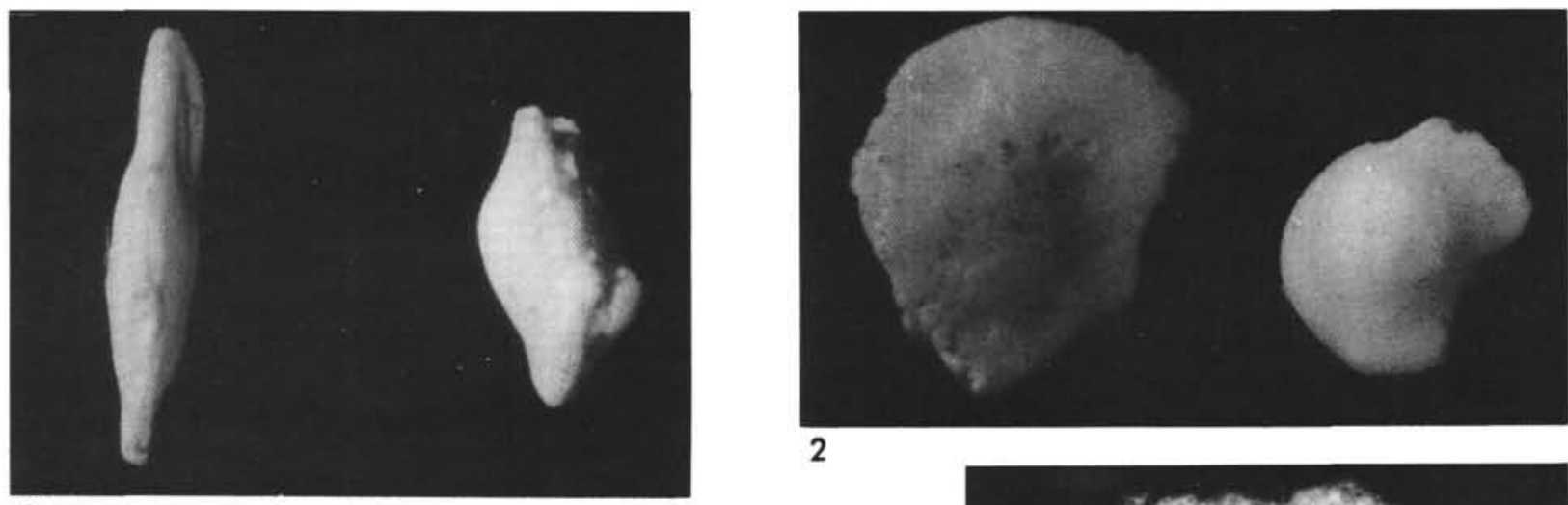

1

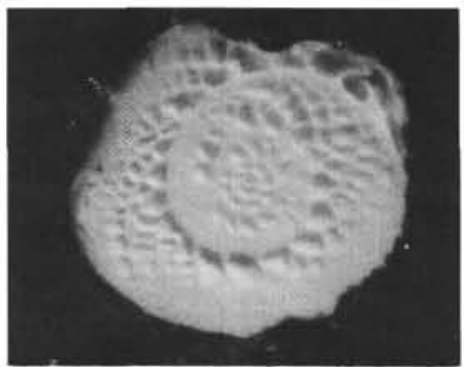

3
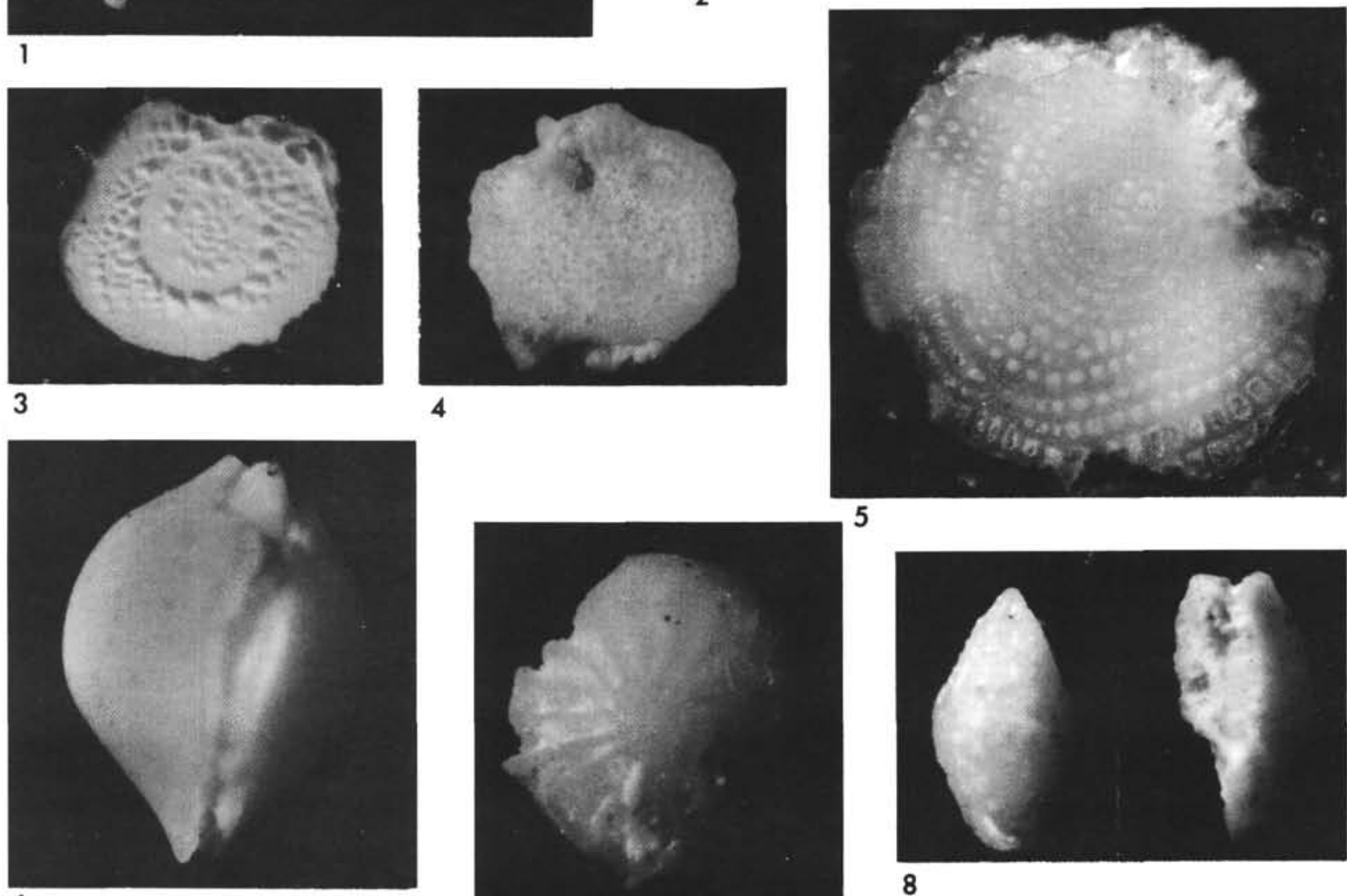

6

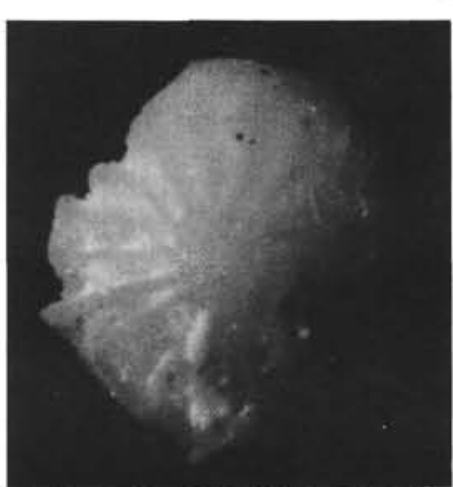

5
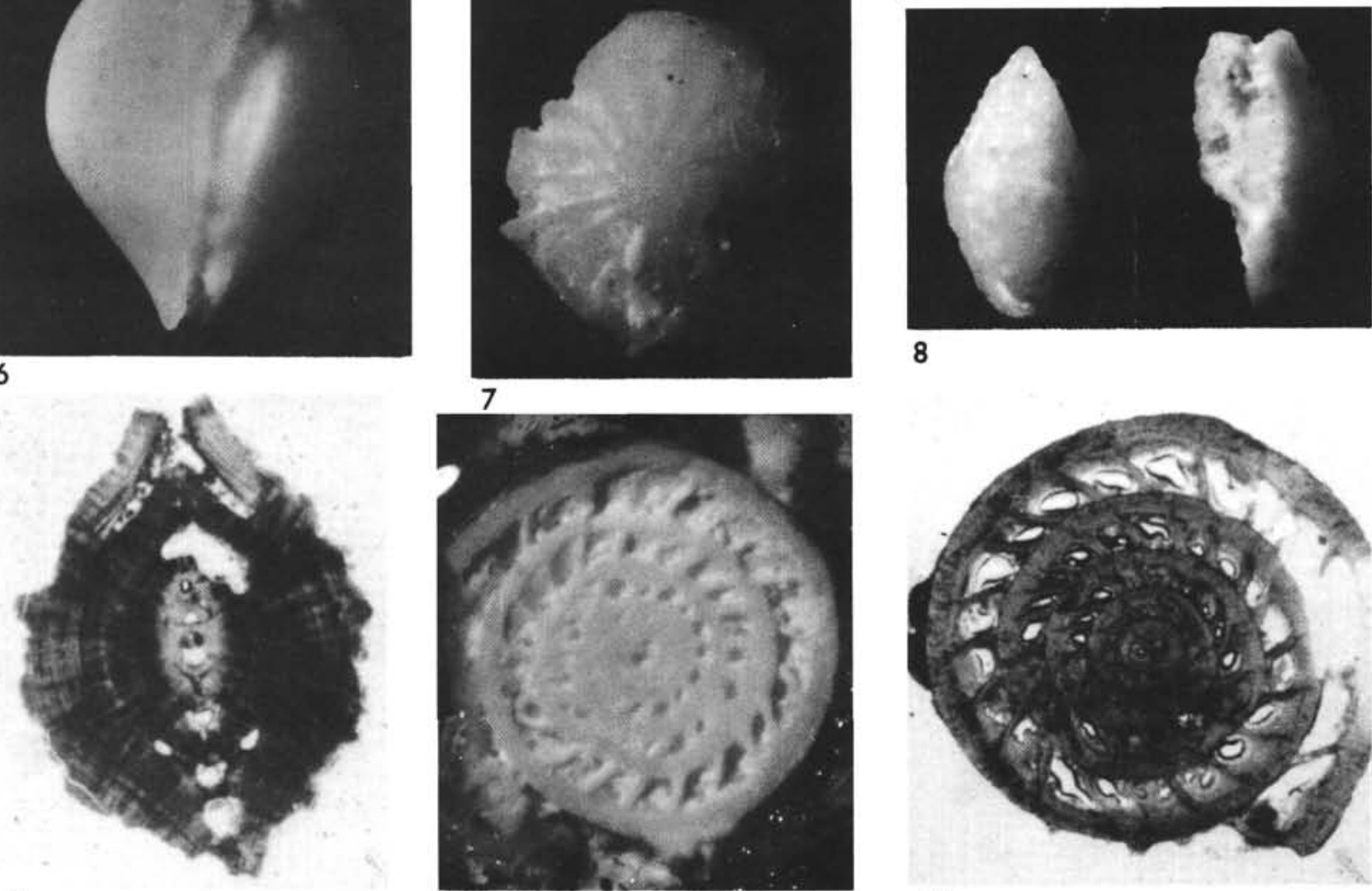

9

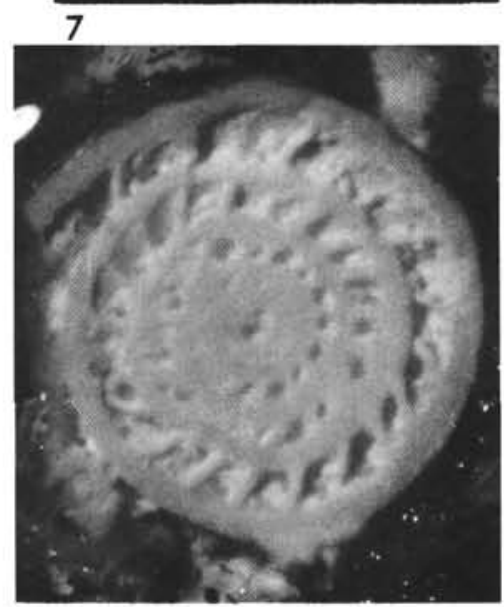

10

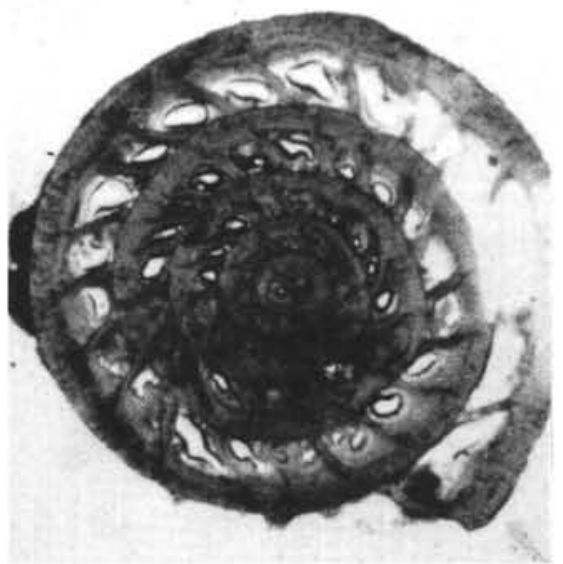

11 


\section{PLATE 9}

Microfossils from Sample 318-19-2, 134-138 cm

(Figure 1) and Sample 318-26-1, 137-140 cm (Figures 2-8).

Figure 1

Fragments of undetermined Coelenterata (corals and a stylasterid hydrozoan?), $14 \times$.

Figures 2-8 Details of a thin section of hard limestone.

2. A globorotalid (Truncorotaloides?) and fragments of discocyclinids, $28 \times$.

3. Two globigerinids (Globigerinatheka? to the right), $85 \times$.

$4,5,8$. Tightly packed specimens of Discocyclina and Asterocyclina, $28 \times$.

6. Detail of two specimens of discocyclinids, $75 \times$. 7. Several random sections of globorotalids and globigerinids, $28 \times$. 
PLATE 9

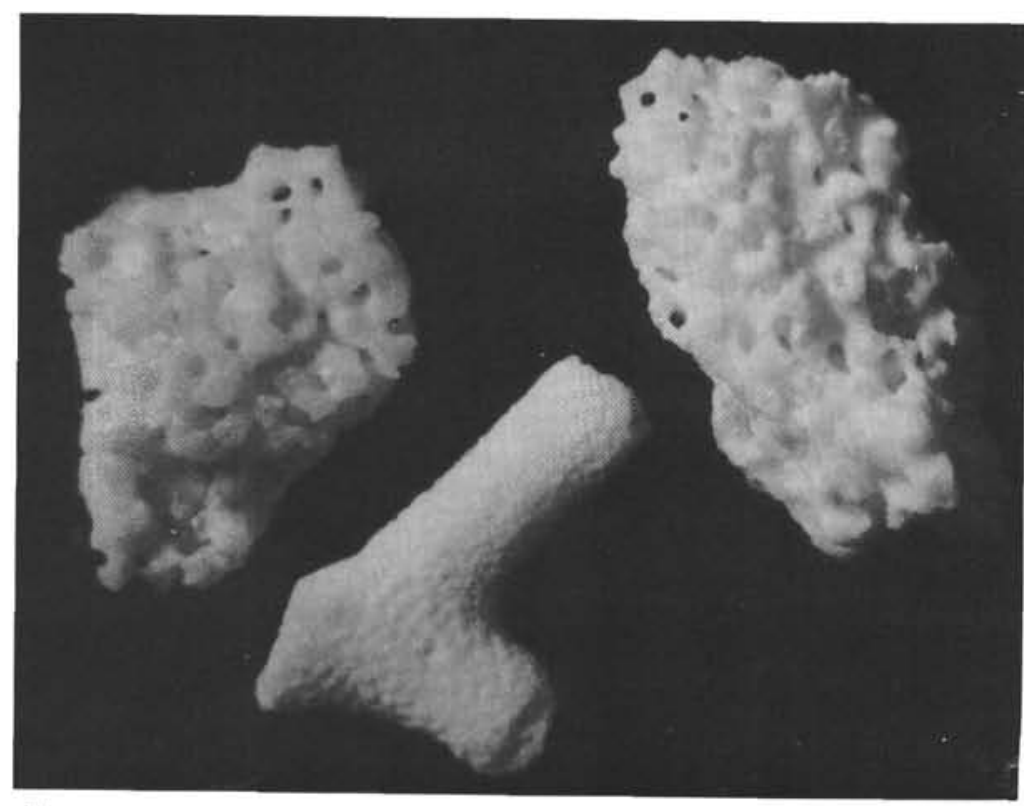

1

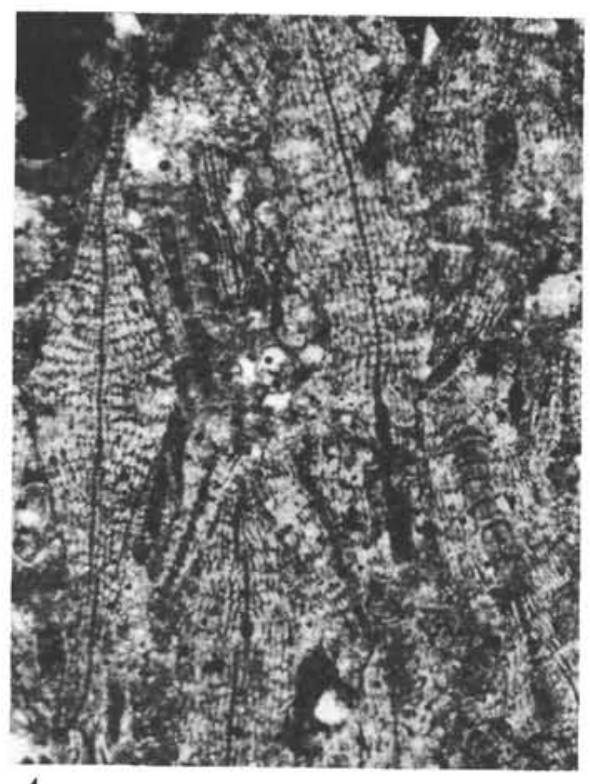

4

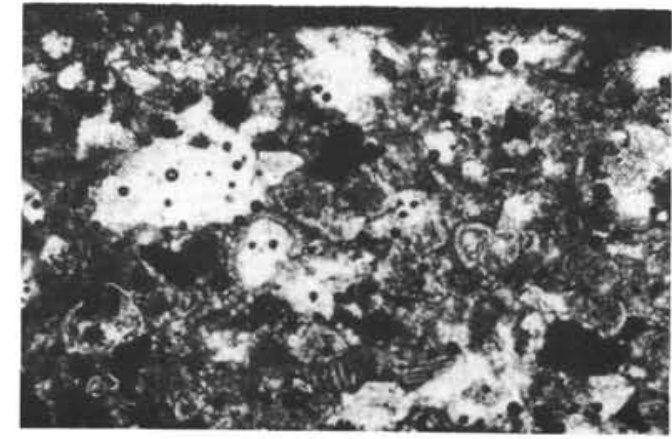

7
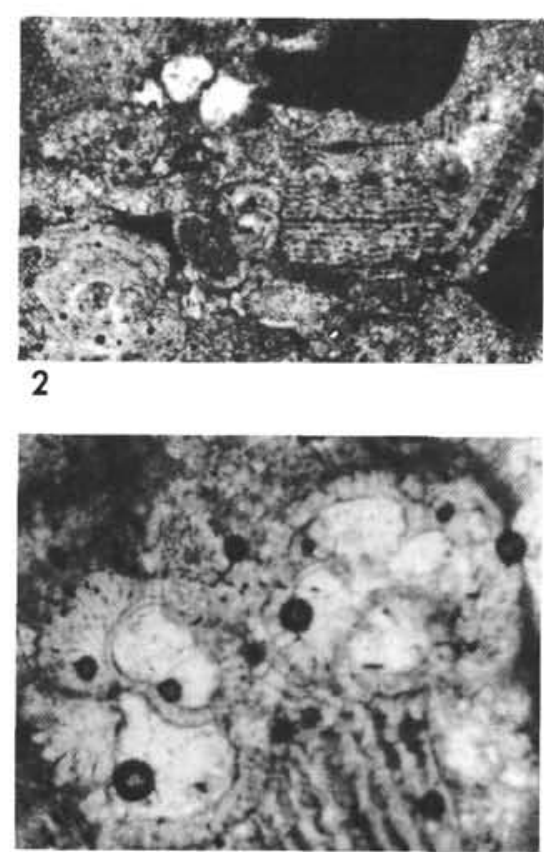

3

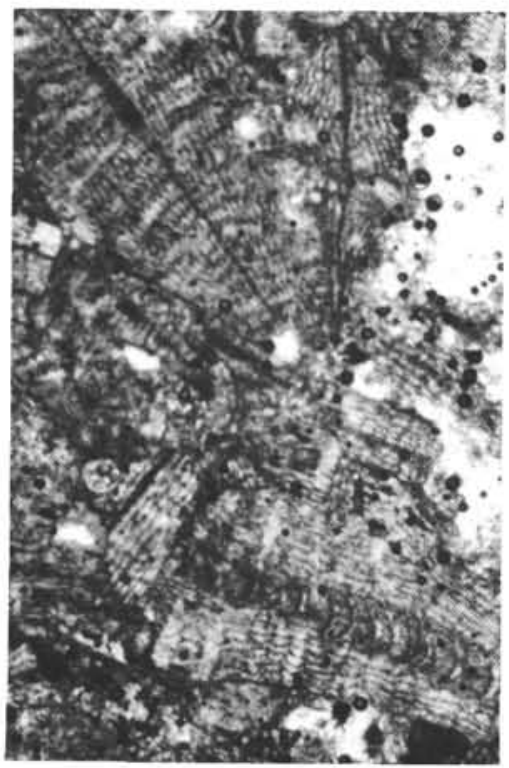

5

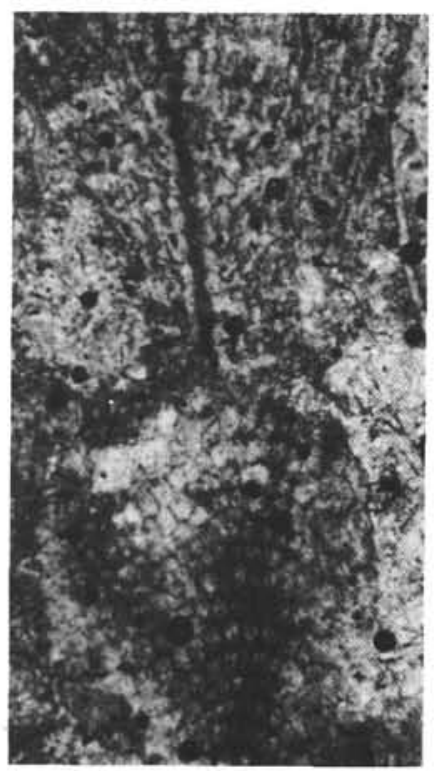

6

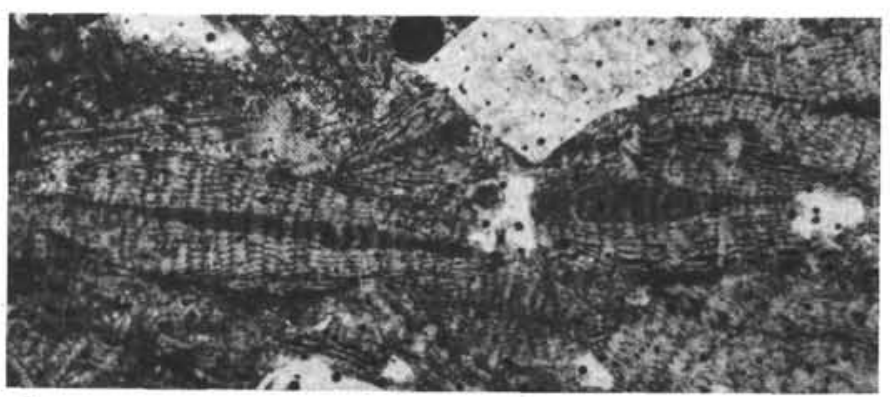

8 